\title{
Modelling deep-water formation in the north-west Mediterranean Sea with a new air-sea coupled model: sensitivity to turbulent flux parameterizations
}

\author{
Léo Seyfried, Patrick Marsaleix, Evelyne Richard, and Claude Estournel \\ Université de Toulouse, CNRS, UPS, Laboratoire d'Aérologie, Toulouse, France \\ Correspondence: Léo Seyfried (leo.seyfried@ aero.obs-mip.fr) \\ Received: 18 May 2017 - Discussion started: 30 May 2017 \\ Revised: 11 October 2017 - Accepted: 25 October 2017 - Published: 22 December 2017
}

\begin{abstract}
In the north-western Mediterranean, the strong, dry, cold winds, the Tramontane and Mistral, produce intense heat and moisture exchange at the interface between the ocean and the atmosphere leading to the formation of deep dense waters, a process that occurs only in certain regions of the world. The purpose of this study is to demonstrate the ability of a new coupled ocean-atmosphere modelling system based on MESONH-SURFEX-SYMPHONIE to simulate a deep-water formation event in real conditions. The study focuses on summer 2012 to spring 2013, a favourable period that is well documented by previous studies and for which many observations are available. Model results are assessed through detailed comparisons with different observation data sets, including measurements from buoys, moorings and floats. The good overall agreement between observations and model results shows that the new coupled system satisfactorily simulates the formation of deep dense water and can be used with confidence to study ocean-atmosphere coupling in the north-western Mediterranean. In addition, to evaluate the uncertainty associated with the representation of turbulent fluxes in strong wind conditions, several simulations were carried out based on different parameterizations of the flux bulk formulas. The results point out that the choice of turbulent flux parameterization strongly influences the simulation of the deep-water convection and can modify the volume of the newly formed deep water by a factor of 2 .
\end{abstract}

\section{Introduction}

The north-west Mediterranean Sea (NWMS) is one of the few regions in the world where the deep open-ocean convection process is regularly observed (Marshall and Schott, 1999). The strong, dry, cold winds, the Tramontane (northwesterly) and the Mistral (northerly), play a major role in this process. These winds induce intense exchanges between the atmosphere and the sea (Flamant, 2003; Hauser et al., 2003), with a marked loss of surface buoyancy (Schott and Leaman, 1991). The oceanic deep convection can be separated into three phases. In autumn, a cyclonic gyre, bound to the north by the Northern Current (NC) (Millot, 1999) and to the south by the North Balearic Front (NBF) (Millot and TaupierLetage, 2005), isolates a weakly stratified water mass whose stratification is progressively eroded by northerly winds (preconditioning phase). In winter, in some years, vertical mixing induced by strong winds leads to the formation of a vertically homogeneous water mass (convective phase) identifiable by its temperature and salinity properties and generally referred to as new western Mediterranean deep water (nWMDW). After the convective phase, the mixed zone undergoes a re-stratification while the nWMDW is spread throughout the basin by the general circulation (Schott et al., 1996) and submesoscale eddies (Testor and Gascard, 2006) (re-stratification/spreading phase).

Two components of the MISTRALS programme (http: //www.mistrals-home.org/) focused on the study of deep convection in the NWMS and made a major effort in collecting observations during 2012 and 2013. The first component, HyMeX (Drobinski et al., 2013), studied the atmosphereland-ocean coupled system. In this context, two special 
observation periods (SOPs) were organized: SOP1 in autumn 2012, during the preconditioning phase (Ducrocq et al., 2013), and SOP2 in winter 2013, during the convection phase (Estournel et al., 2016b). The second component, MerMex (Sempéré et al., 2010), studied the impact of oceanic deep convection on the nutrient balance and the planktonic ecosystem. Three oceanographic cruises were organized by MerMex: DOWEX in autumn 2012, DEWEX leg 1 in February 2013 and DEWEX leg 2 in April 2013. Combining all these different surveys provided a good description of the spatial distribution and temporal evolution of ocean stratification. Furthermore, the volume of dense water formed by deep convection could be evaluated thanks to the optimal interpolation of the many conductivity-temperature-depth (CTD) profiles available (Waldman et al., 2016b). This series of campaigns provided a unique opportunity to test the ability of models to simulate the different phases of the dense water formation process in the western Mediterranean.

Several modelling studies of the formation of deep water in the NWMS have been carried out over different periods and with different models (e.g. Herrmann et al., 2008, 2010; Herrmann and Somot, 2008; Léger et al., 2016; Estournel et al., 2016a; Waldman et al., 2016a). Their results show high sensitivity to the initial stratification of the ocean model and to the accuracy of the atmospheric forcing. An attempt to progress on these two issues was proposed by the HyMeX and MerMex groups. Concerning the first point, since 2010, oceanographic cruises have been organized in the NWMS each summer by the Mediterranean Ocean Observing System for the Environment (MOOSE; www.moose-network.fr/). These cruises provide a sample of the different water masses of the NWMS based on about 70 CTD profiles. In particular, the observations collected in summer 2012 have been assimilated to provide a more realistic initial state for ocean models (Estournel et al., 2016a; Léger et al., 2016) which has been shown to be crucial for the simulation of the winter convection 6 months later. Regarding the atmospheric forcing, the benefit of using a fully coupled system to study air-sea interactions in numerical weather prediction models was already illustrated in previous studies based upon different airsea coupled systems (e.g. Lebeaupin Brossier and Drobinski, 2009; Small et al., 2012; Renault et al., 2012). These studies have shown that coupled simulations provide a better representation of atmospheric and oceanic surface parameters compared to uncoupled simulations. In particular, during strong wind event coupled simulations capture the rapid sea surface temperature (SST) cooling more accurately, which makes the atmospheric boundary layer more stable and reduces the heat and moisture exchanges. It is likely that this improved representation of the atmospheric forcing could also lead to an improved representation of the deep-water formation.

Besides the question related to coupling, there is still significant uncertainty as to the choice of a relevant parameterization to compute the turbulent fluxes for strong wind conditions such as the Mistral and Tramontane. Current parameterizations have been carefully assessed and validated against large data sets. However, due to the limited number of available observations in strong wind conditions, they are known to be inaccurate for wind speeds exceeding $20 \mathrm{~m} \mathrm{~s}^{-1}$ (e.g. Hauser et al., 2003). The sensitivity tests performed by Estournel et al. (2016a) suggest that the uncertainty associated with the turbulent flux computations could have a strong impact on the deep-water formation process in the NWMS.

These issues, among others, have motivated the recent development of a new coupling platform (SURFEX OASIS3MCT) providing better numerical tools to address the scientific and technical questions related to ocean-waveatmosphere coupling (Voldoire et al., 2017). This coupling platform is based on the multi-surface model SURFEX (Masson et al., 2013) and on the OASIS3-MCT (Craig et al., 2017) code coupler. SURFEX computes the surface-atmosphere fluxes over four surface types (land, town, ocean and inland waters) and can be used in a stand-alone version with prescribed atmospheric forcing or embedded in an atmospheric model. The use of OASIS3-MCT allows SURFEX to be linked to various other models including ocean, land, atmosphere, hydrology, waves and sea-ice models. This generic coupling strategy based upon an externalized surface model ensures that the surface flux computations are done in a consistent way, independently of the models to be coupled. As illustrated in Voldoire et al. (2017), this strategy has greatly facilitated the coupling of the different models developed in the French community, including the coupling of the MESONH atmospheric model (Lafore et al., 1997) and the SYMPHONIE ocean model (Marsaleix et al., 2008, 2009, 2012).

A first objective of the present study is to show the capacity of the new coupled regional ocean-atmosphere system MESONH-SURFEX-SYMPHONIE to reproduce the formation of deep dense waters during the winter of 2013 in the NWMS. A second objective is to study the sensitivity of the simulations to the parameterization of the turbulent surface fluxes by testing three different parameterizations (Fairall et al., 2003; Andreas et al., 2015; Moon et al., 2007), all based on bulk formulas.

This paper is organized as follows. Section 2 describes the coupled modelling system and the three parameterizations mentioned above that were used for the computation of turbulent fluxes. Section 3 presents the different observation data sets used to evaluate the model results, while Sect. 4 details the setup of the numerical experiments. Results are analysed and discussed in Sect. 5. Some conclusions and perspectives are presented in Sect. 6. 
Table 1. Main characteristics of the atmospheric and oceanic model configurations.

\begin{tabular}{|c|c|c|}
\hline Physical processes & Schemes & References \\
\hline \multicolumn{3}{|l|}{ Atmospheric model } \\
\hline Horizontal grid & Arakawa $\mathrm{C}$ grid, $10 \mathrm{~km}$ resolution & \\
\hline Vertical levels & $\begin{array}{l}\text { Sigma- } z \text { coordinates, } 52 \text { vertical levels } \\
\text { from } 15 \text { to } 15000 \mathrm{~m}\end{array}$ & \\
\hline Turbulence & TKE, 1-D vertical & Cuxart et al. (2000) \\
\hline Convection & Mass flux & Bechtold et al. (2001); Pergaud et al. (2009) \\
\hline Radiation & $\begin{array}{l}\text { Longwave: RRTM; } \\
\text { shortwave: ECMWF }\end{array}$ & $\begin{array}{l}\text { Mlawer et al. (1997); } \\
\text { Fouquart and Bonnel (1980) }\end{array}$ \\
\hline Microphysics & ICE3 & $\begin{array}{l}\text { Caniaux et al. (1994); } \\
\text { Pinty and Jabouille (1998) }\end{array}$ \\
\hline Initial and boundary conditions & ECMWF analyses & \\
\hline \multicolumn{3}{|l|}{ Oceanic model } \\
\hline Horizontal grid & $\begin{array}{l}\text { Curvilinear Arakawa } \mathrm{C} \text { grid, } \\
1 \mathrm{~km} \text { resolution }\end{array}$ & Bentsen et al. (1999) \\
\hline Vertical levels & 40 generalized sigma vertical levels & Ulses et al. (2008) \\
\hline Sea surface conditions & $\begin{array}{l}\text { Craig \& Banner TKE boundary } \\
\text { conditions }\end{array}$ & Estournel et al. (2009) \\
\hline Mixing & Eddy kinetic energy & Gaspar et al. (1990) \\
\hline Convection & Penetrative convection & Deardorff et al. (1969); Estournel et al. (2016a) \\
\hline River input & Lateral condition ( 15 river inputs) & Estournel et al. (2009) \\
\hline Initial and boundary conditions & $\begin{array}{l}\text { MERCATOR-OCEAN } \\
\text { MOOSE 2012-2013 }\end{array}$ & Lellouche et al. (2013); Estournel et al. (2016a) \\
\hline
\end{tabular}

\section{Model description}

\subsection{Air-sea coupled model}

The modelling system is based on the non-hydrostatic atmospheric model, MESONH (Lafore et al., 1997, http:// mesonh.aero.obs-mip.fr/mesonh52/), developed at the Laboratoire d'Aérologie (LA) and Centre National de Recherches Météorologiques (CNRM), the multi-surface model SURFEX (Masson et al., 2013, http://www.cnrm-game-meteo. fr/surfex/) developed at CNRM and the Boussinesq hydrostatic ocean model SYMPHONIE (Marsaleix et al., 2008, 2009, 2012, http://sirocco.omp.obs-mip.fr/ocean_models/ $\mathrm{S}$-model) developed at LA. These models are coupled through the SURFEX-OASIS3-MCT interface (Voldoire et al., 2017). The main characteristics of the atmospheric and oceanic model configurations are listed in Table 1 . The oceanic model uses a horizontal resolution of $1 \mathrm{~km}$. Given the value of the Rossby radius (5-10 km in the NWMS), $1 \mathrm{~km}$ grid spacing appears to constitute a reasonable compromise between the computing cost and the necessary resolution. In the vertical, 40 generalized sigma levels are used, with 10 of them in the first hundred metres (above the abyssal plain). The resolution just below the sea surface is $1.5 \mathrm{~m}$. The atmospheric model is run with a $10 \mathrm{~km}$ horizontal grid spacing and 52 terrain-following vertical levels ranging from 15 to $15000 \mathrm{~m}$, with 16 of them in the first kilometres. With such resolutions, both atmospheric and oceanic convection must be parameterized. In the case of the ocean, the vertical diffusion is parameterized following Gaspar et al. (1990) with a prognostic equation for the turbulent kinetic energy and a diagnostic relation for the mixing and dissipation lengths. A $1 \mathrm{~km}$ resolution is still too coarse to explicitly resolve convective plumes, which thus need to be parameterized. Different parameterizations have been proposed (e.g. Marsland et al., 2003). The most common and basic one consists in artificially increasing the vertical diffusion coefficient in statically unstable layers (e.g.s Waldman et al., 2016a). In our case, the heat and water fluxes are linearly distributed over the whole mixed layer. The mixed layer is given by the depth at which the vertical density gradient becomes negative. By doing so, the first level under the surface does not support the entire amount of heat loss by itself, which prevents the development of static instabilities at the surface. Furthermore, this parameterization is consistent with the nearly linear vertical variation of the buoyancy flux in the convective layer (Deardorff et al., 1969). Regarding the atmosphere, shallow and deep convection are parameterized with mass-flux schemes according to Bechtold et al. (2001) and Pergaud et al. (2009), respectively.

In the coupled system, the surface fluxes are computed by SURFEX on the atmospheric model grid. They are sent to the ocean model by the OASIS3-MCT coupler, which also performs their interpolation on the ocean model grid. Con- 


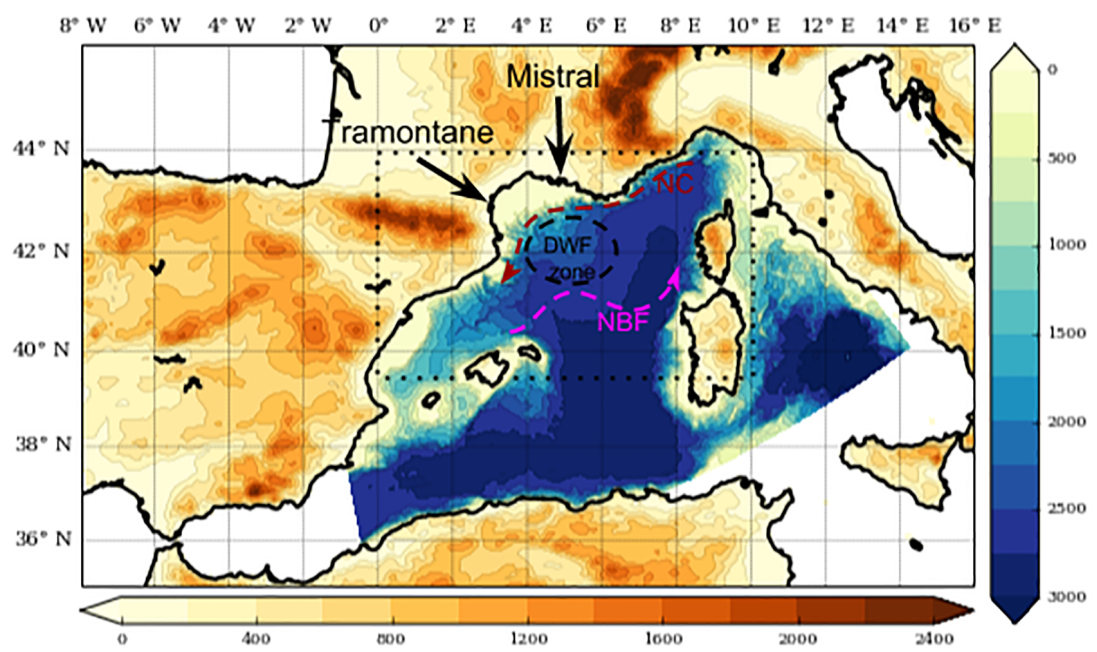

Figure 1. Full frame: spatial extension of the atmospheric model including topography (metres, horizontal colour bar, positive above sea level) and bathymetry (metres, vertical colour bar, negative below sea level) of the ocean model. The black dotted rectangle indicates the area studied. The red and magenta dotted lines represent oceanic surface circulation with the Northern Current (NC) and North Balearic Front (NBF), respectively. The black dotted circle indicates the dense water formation (DWF) zone.

versely, the ocean model computes the sea surface temperature and sends it to SURFEX using the OASIS3-MCT coupler, which takes care of its interpolation on the atmospheric model grid. The coupling frequency is set to $10 \mathrm{~min}$ and the interpolation between the two model grids is bilinear.

The computational domains used for this study are presented in Fig. 1. The atmospheric grid covers the whole western Mediterranean Basin, while only part of it is covered by the ocean grid (blue area in Fig. 1) since the Alboran Sea and part of the Tyrrhenian Sea were excluded to avoid strait issues. Outside the ocean grid, the air-sea fluxes are computed using the sea surface temperature provided by the OSTIA database (Donlon et al., 2012), the horizontal resolution of which is about $6 \mathrm{~km}$.

\subsection{Turbulent flux parameterizations}

Turbulent air fluxes at the air-sea interface are computed from bulk type parameterizations based on the MoninObukhov similarity theory (Foken, 2006). These parameterizations compute the turbulent fluxes as

$|\tau|=\rho_{\mathrm{a}} u^{* 2}$,

$\mathrm{H}=-\rho_{\mathrm{a}} C_{\mathrm{p}} u^{*} \theta^{*}$,

$\mathrm{LE}=-\rho_{\mathrm{a}} L_{e} u^{*} q^{*}$,

where $\tau$ is the momentum flux, $H$ the sensible heat flux, LE the latent heat flux, $\rho_{\mathrm{a}}$ the air surface density and where $u^{*}, \theta^{*}$ and $q^{*}$ are scaling parameters for momentum, potential temperature and humidity, respectively. The momentum scale, $u^{*}$, is referred to as friction velocity.

Classically, the scale parameters are expressed as a function of the vertical gradients of the mean fields at the air-sea interface, the surface roughness and the atmospheric stability. Although based upon the same formalism, the turbulent flux parameterizations differ in the way they specify the different roughness lengths and the so-called stability functions. In particular, the validity of Charnock's formulation (Charnock, 1955) which is generally used to relate $u^{*}$ to the dynamic roughness length has often been questioned for strong wind conditions.

In this study, three well-established parameterizations have been used.

- The COARE3.0 parameterization (Fairall et al., 2003) is one of the most widely used in the modelling community. This parameterization derives from the COARE2.6 algorithm (Fairall et al., 1996) originally developed from the observations performed during the TOGACOARE experiment (Webster and Lukas, 1992) in the North Pacific. An important upgrade in COARE3.0 is a new formulation of the surface (dynamic and scalar) roughness lengths which slightly increases the fluxes for wind speeds exceeding $10 \mathrm{~m} \mathrm{~s}^{-1}$. Although COARE3.0 has been validated against a much larger data set ( 7000 observations) than the one used for COARE2.6, COARE3.0 remains mostly reliable for wind speeds below $20 \mathrm{~m} \mathrm{~s}^{-1}$ due to the limited number of observations available in strong wind conditions. It is worth noting that the influence of waves (available as two possible options in COARE3.0 but not extensively validated) was not activated in our study.

- The ANDREAS parameterization (Andreas et al., 2015) is a novel and more physically based approach which distinguishes two different contributions to the turbulent heat fluxes: the standard air-sea interfacial fluxes con- 
(a)

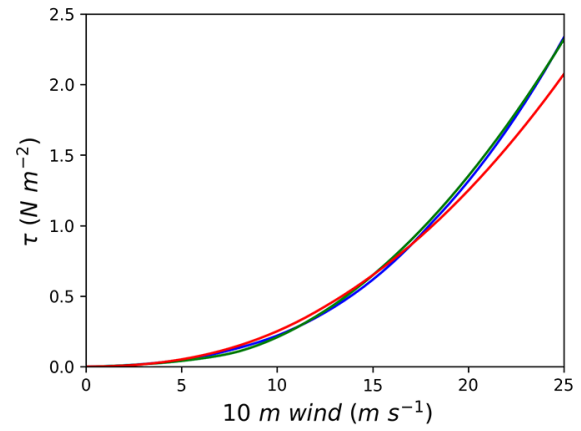

(b)

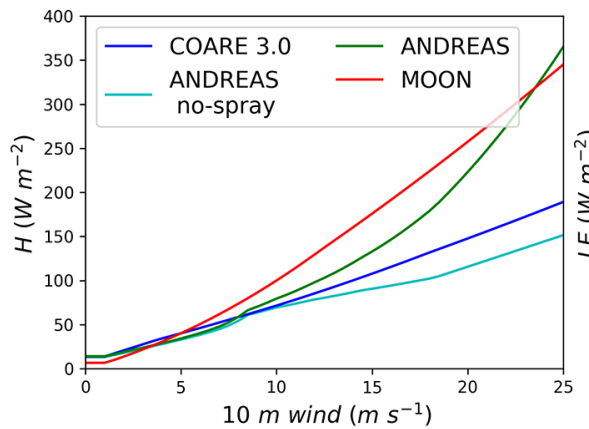

(c)

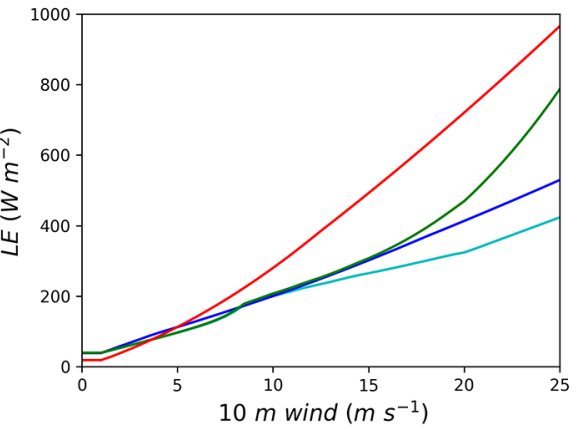

Figure 2. Turbulent fluxes of momentum (a), sensible heat (b) and latent heat (c) as functions of the surface wind speed for each bulk parameterization (COARE3.0 in blue, ANDREAS no-spray in cyan, ANDREAS in green and MOON in red). The computation was performed with SURFEX offline, with the air surface temperature fixed at $10^{\circ} \mathrm{C}$, the sea surface temperature at $15^{\circ} \mathrm{C}$, the relative humidity at $70 \%$ and the surface atmospheric pressure at $1013 \mathrm{hPa}$.

trolled by molecular processes right at the air-sea interface on the one hand, and the sea-spray fluxes controlled by microphysical processes around sea-spray droplets on the other hand. As opposed to the COARE-type algorithm, the friction velocity used to compute the interfacial fluxes is parameterized as a function of the $10 \mathrm{~m}$ wind speed at neutral stability, eliminating thereby the uncertainty associated with the definition of the dynamic roughness length and the use of the Charnock (1955) expression. The sea-spray contribution becomes notable only for wind speeds exceeding $13 \mathrm{~m} \mathrm{~s}^{-1}$. Small droplets are then ejected by surface waves into the atmospheric surface layer. They cool, evaporate and can significantly contribute to the air-sea exchanges of heat and water. The sea-spray fluxes are computed using the fast microphysical algorithm described in Andreas (2005). ANDREAS parameterization has been established with a data set of $\sim 4000$ observations with wind speeds up to almost $25 \mathrm{~m} \mathrm{~s}^{-1}$.

- As opposed to COARE and ANDREAS, the MOON parameterization (Moon et al., 2007) mainly relies upon model results. It has been developed based upon the results of a coupled wave-wind model. The simulations of 10 idealized tropical cyclones have been used to derive a new expression of the dynamic roughness length, which limits the increase of friction velocity with wind for wind speeds exceeding $12.5 \mathrm{~m} \mathrm{~s}^{-1}$. This new formulation was indirectly validated using the Geophysical Fluid Dynamics Laboratory coupled hurricane-ocean prediction model (Kurihara et al., 1998). For five hurricanes observed in the Atlantic Ocean, the new formulation led to better results than the former one (based upon Charnock's formulation) with a clear improvement of the cyclone intensity and no degradation of its track and central pressure.
COARE3.0 is the standard parameterization used in SURFEX, while ANDREAS and MOON were implemented in SURFEX specifically for the purposes of the study.

To illustrate the discrepancies between these parameterizations, Fig. 2 shows the turbulent fluxes plotted as a function of the $10 \mathrm{~m}$ wind speed and computed with the different parameterizations. Although not used further in the following, the results of ANDREAS without the sea-spray effect (ANDREAS no-spray) have been added for completeness. The computations were carried out under unstable conditions typical of the Mistral and Tramontane events: the $10 \mathrm{~m}$ air temperature fixed at $10^{\circ} \mathrm{C}$, the sea surface temperature at $15^{\circ} \mathrm{C}$ and the $10 \mathrm{~m}$ relative humidity at $70 \%$. In these conditions, COARE3.0 and ANDREAS produced very similar momentum fluxes, while the MOON momentum flux was found to be slightly weaker but only for the strongest winds $\left(>15 \mathrm{~m} \mathrm{~s}^{-1}\right)$. For the sensible heat flux, COARE3.0 and ANDREAS provided close results up to a wind speed $8 \mathrm{~m} \mathrm{~s}^{-1}$ but, for higher wind speeds, the impact of the sea spray considerably enhanced the ANDREAS sensible heat flux. Among the three parameterizations, MOON was the one that produced the strongest sensible heat flux over a wide range of wind speeds (from 6 to $23 \mathrm{~m} \mathrm{~s}^{-1}$ ). The latent heat fluxes presented the same hierarchy in intensity as the sensible heat fluxes. However, the difference between COARE3.0 and ANDREAS only occurred from wind speeds greater than $16 \mathrm{~m} \mathrm{~s}^{-1}$ (as compared to $8 \mathrm{~m} \mathrm{~s}^{-1}$ for the sensible heat flux). To summarize, the three parameterizations gave significantly different results, particularly MOON, which produced the largest turbulent heat fluxes in a wide range of wind speeds. It should also be noted that the differences between the parameterizations may become noticeable from wind speeds as low as $8 \mathrm{~m} \mathrm{~s}^{-1}$ and can dramatically increase with the wind speed, especially for the heat fluxes. 


\section{Available observations}

Several in situ data sets, collected by the MOOSE, HyMeX and MerMex programmes, are used in the present study and are briefly described below. More details are available in Estournel et al. (2016b). First, the Lion meteorological buoy provides hourly measurements of the air temperature and humidity at $2 \mathrm{~m}$ above the sea surface, the wind speed at $10 \mathrm{~m}$ and the sea surface temperature. A mooring named LION, part of the MOOSE network, and located only $5 \mathrm{~km}$ away from the Lion buoy, is also available. It provides vertical profiles of temperature and salinity, sampled over 21 levels for temperature and 15 for salinity, between 150 and $2300 \mathrm{~m}$ deep (Houpert et al., 2016).

In addition, several oceanographic cruises were carried out in the NWMS during 2012-2013 (Waldman et al., 2016b). In August 2012, the annual cruise organized by MOOSE for the monitoring of the NWMS provided 69 vertical surfaceto-bottom profiles of temperature and salinity. The same network of CTD stations was deployed in February and April 2013 during the DEWEX leg 1 and leg 2 cruises. A smaller network was implemented in autumn 2012 during the DOWEX cruise, with only 41 profiles. Furthermore, 399 temperature and salinity profiles measured by 14 ARGO floats, 4 of them specifically deployed by HyMeX with a daily cycle, are also taken into consideration in this study. The above-mentioned cruises allowed the spatial distribution and temporal evolution of ocean stratification to be well described. Ocean stratification is commonly assessed using the stratification index (SI; Eq. 4).

$\mathrm{SI}(Z)=\int_{Z}^{0}(\rho(Z)-\rho(z)) \mathrm{d} z$,

where $\rho$ is the potential density and $Z$ the reference level. SI is expressed in $\mathrm{kg} \mathrm{m}^{-2}$. Note that $\operatorname{SI}(Z)=0$, which means that the water column is mixed at least to depth $Z$ or, in other words, that the mixed layer depth is greater than or equal to $Z$.

Figure 3a-d show the SI at $1000 \mathrm{~m}$ (Eq. 4) for each seasonal cruise and Fig. 3e its time evolution from summer 2012 to spring 2013. In summer (Fig. 3a), the most stratified water $\left(\operatorname{SI}(1000 \mathrm{~m})>120 \mathrm{~kg} \mathrm{~m}^{-2}\right)$ present in the south corresponds to recent Atlantic Water (AW), while the less stratified water $\left(\operatorname{SI}(1000 \mathrm{~m})<80 \mathrm{~kg} \mathrm{~m}^{-2}\right)$, confined to the north of the deep basin (above $42^{\circ} \mathrm{N}$ ), corresponds to an older Atlantic water mass, which along its pathway in the Mediterranean Basin has been modified under the effect of surface heat fluxes and of vertical mixing in the convective regions. These two water masses are separated by the North Balearic Front. In autumn (Fig. 3b), the northward displacement of this front brings AW toward the north of the basin, whereas the oceanic stratification increases in the south of the domain. In winter (Fig. 3c), the oceanic deep convection is revealed by many profiles with $\mathrm{SI}(1000 \mathrm{~m})<1 \mathrm{~kg} \mathrm{~m}^{-2}$, meaning that these profiles are mixed down to $1000 \mathrm{~m}$ depth. When the vertical mixing reaches the seafloor, it can then lead to the formation of dense deep water. Finally, in spring (Fig. 3d), re-stratification occurs with an increase of stratification in the convective area $\left(\mathrm{SI}(1000 \mathrm{~m})>10 \mathrm{~kg} \mathrm{~m}^{-2}\right)$.

Combining all these available observations, Waldman et al. (2016a) estimated the volume of the dense deep water formed at $4.5( \pm 1.1) \times 10^{13} \mathrm{~m}^{3}$ (for density greater than $29.11 \mathrm{~kg} \mathrm{~m}^{-3}$ ) between summer 2012 (MOOSE 2012 cruise) and spring 2013 (DEWEX leg 2 cruise) in the convective area defined between $\left[2.5^{\circ} \mathrm{E} ; 9^{\circ} \mathrm{E}\right]$ and $\left[40^{\circ} \mathrm{N} ; 44^{\circ} \mathrm{N}\right]$ and limited by the $2000 \mathrm{~m}$ bathymetry contour (red line in Fig. 3ad).

\section{Numerical experiments}

To model this well-documented event of dense water formation in the NWMS, three coupled simulations are reported here. They differ only in their turbulent flux formulation and are named COARE, ANDREAS and MOON according to their parameterizations. These simulations start on $16 \mathrm{Au}-$ gust 2012 with a realistic initial oceanic state and end on 1 May 2013. Initial and boundary conditions of the atmospheric model are provided by the $6 \mathrm{~h}$ analyses produced by the European Centre for Medium-Range Weather Forecasts (ECMWF) with a horizontal resolution of $1 / 8^{\circ}$. Initial and boundary conditions of the ocean model are provided by the analyses of the MERCATOR-OCEAN operational centre (Lellouche et al., 2013) based on the NEMO ocean model (Maraldi et al., 2013). These ocean fields are corrected according to the method proposed by Estournel et al. (2016a). Practically, the vertical background stratification is corrected using the CTD profiles of the MOOSE 2012 oceanographic cruise. Estournel et al. (2016a) show that this correction is necessary to properly simulate the preconditioning phase and the triggering of the convective phase. In this study, to also improve the sea surface temperature initial state, the surface temperature is restored toward the SST satellite data (Buongiorno Nardelli et al., 2013) during the 14 days preceding the beginning of the simulations using a restoring timescale of 3 days. At the end of this process, we obtain a surface temperature that closely matches the satellite observation of 16 August 2012. During the rest of the simulation, the coupled model evolves freely, without further data assimilation and without any restoring or nudging procedure. 


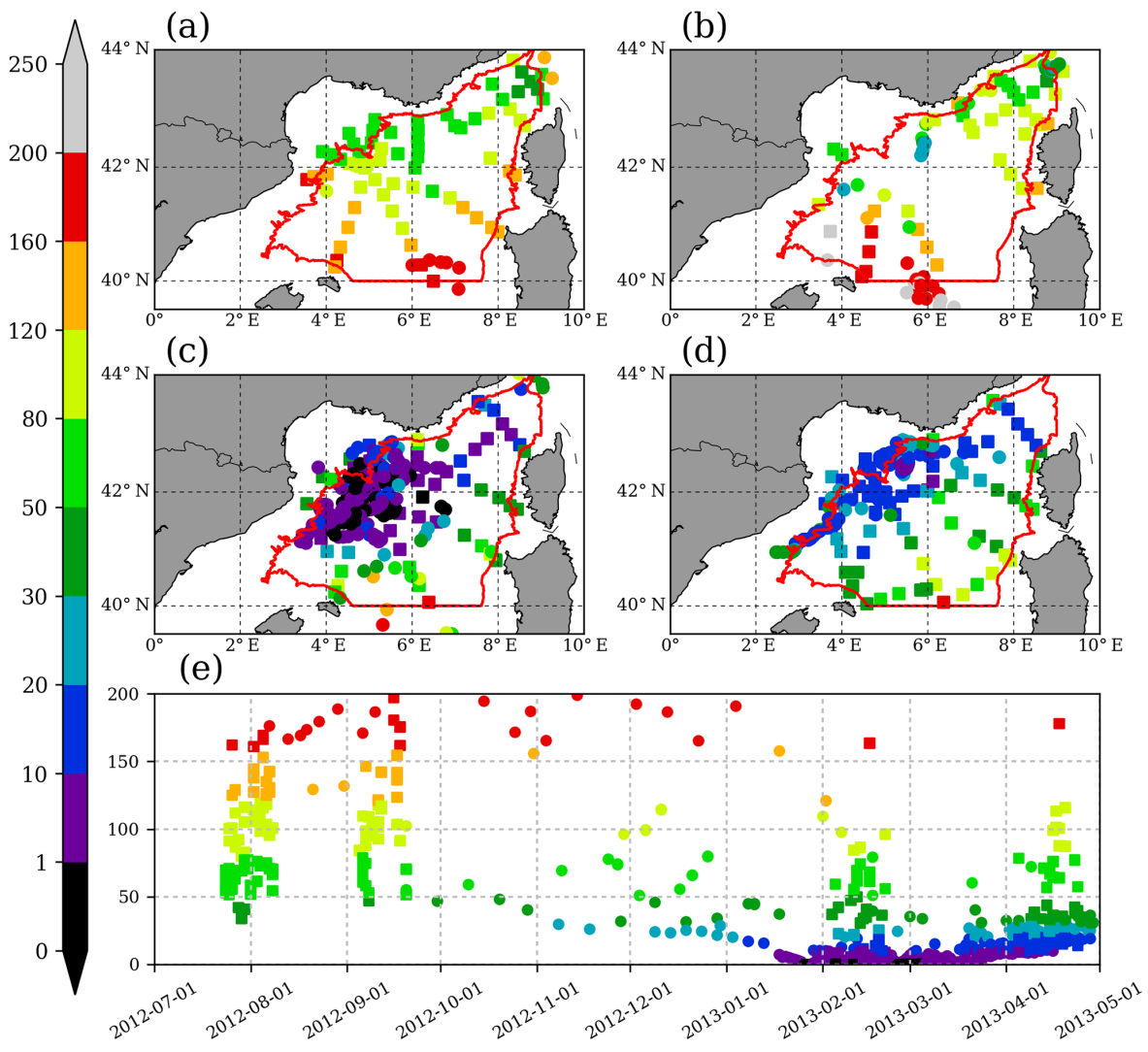

Figure 3. Stratification index at $1000 \mathrm{~m}$ derived from CTD (squares) and ARGO (dots). Observations during (a) summer 2012 (MOOSE), (b) autumn 2012 (DOWEX), (c) winter 2013 (DEWEX leg 1) and (d) spring 2013 (DEWEX leg 2). (e) Time series of the stratification index at $1000 \mathrm{~m}$. The red contour corresponds to the convective area defined in Sect. 3.

\section{Results}

\subsection{Air-sea exchanges at the Lion meteorological buoy}

\subsubsection{Atmospheric and oceanic surface parameters}

A first evaluation of the simulations is carried out by comparing the computed fields with the corresponding measurements at the Lion buoy. This buoy has already been used in various previous studies to validate atmospheric and/or oceanic simulations (Lebeaupin Brossier et al., 2014; Léger et al., 2016; Rainaud et al., 2016). Figure 4 shows the temporal evolution of surface atmospheric and oceanic parameters $(10 \mathrm{~m}$ wind speed, $2 \mathrm{~m}$ temperature and humidity and sea surface temperature) computed at the buoy, together with the corresponding observations. The same surface parameters are also presented in Fig. 5 in the form of scatter plots (simulations versus observations) while the associated statistics (bias, root mean square error and correlation coefficient) are given in Table 2 .

Figure $4 \mathrm{a}$ allows the strong Tramontane and Mistral events to be identified (with hourly wind speeds exceeding $15 \mathrm{~m} \mathrm{~s}^{-1}$ outlined in grey), alternating with calm wind situations. The Mistral and Tramontane episodes are systematically accom- panied by marked drops in temperature and moisture (Fig. 4b and c). By a cumulative effect, the succession of strong wind events in autumn leads to a progressive decrease of the sea surface temperature (Fig. 4d), which reaches its minimum value of $12.9^{\circ} \mathrm{C}$ (i.e. the temperature of the deep water) in early winter and then remains nearly constant during the convective period.

All three simulations accurately reproduce the time evolution of the wind speed at the buoy throughout the 8-month period, with a correlation of 0.9 and a bias lower than $0.2 \mathrm{~m} \mathrm{~s}^{-1}$. In particular, the timing of the strong wind events is well captured. Moreover, the wind speed maxima are well represented (Fig. 5a), which is essential to correctly reproduce the intense air-sea exchanges associated with convection (Herrmann and Somot, 2008). Finally, there is no significant difference in wind speed between the different simulations (Figs. 4a, 5a and Table 2).

For the other surface atmospheric parameters ( $2 \mathrm{~m}$ air temperature and relative humidity), slightly larger discrepancies are found from one simulation to another. Air temperature and humidity remain relatively close to observations in terms of correlation (respectively, 0.98 and 0.85 ; Table 2). Bias and root mean square error exhibit larger but still weak differ- 
(a)

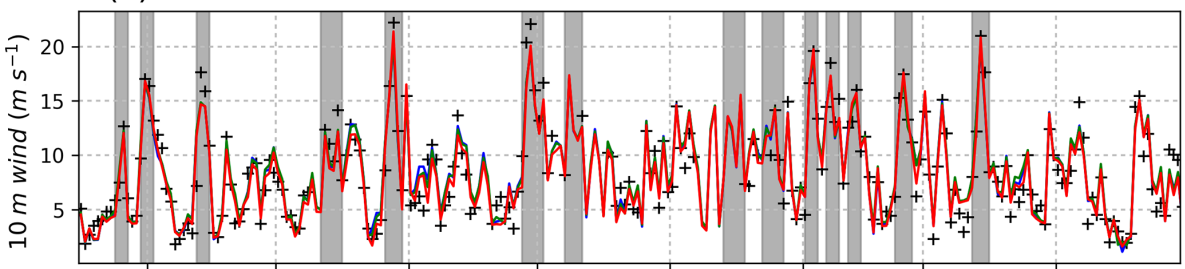

(b)

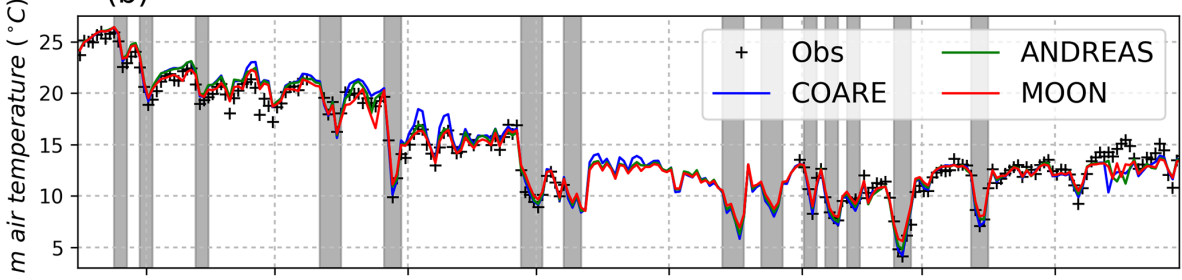

(c)

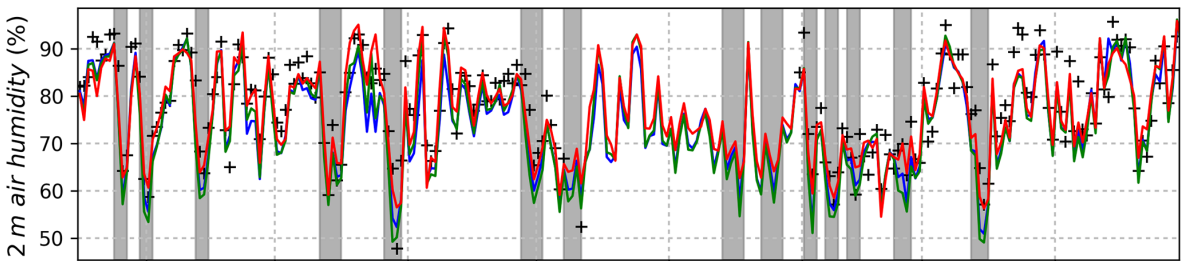

(d)

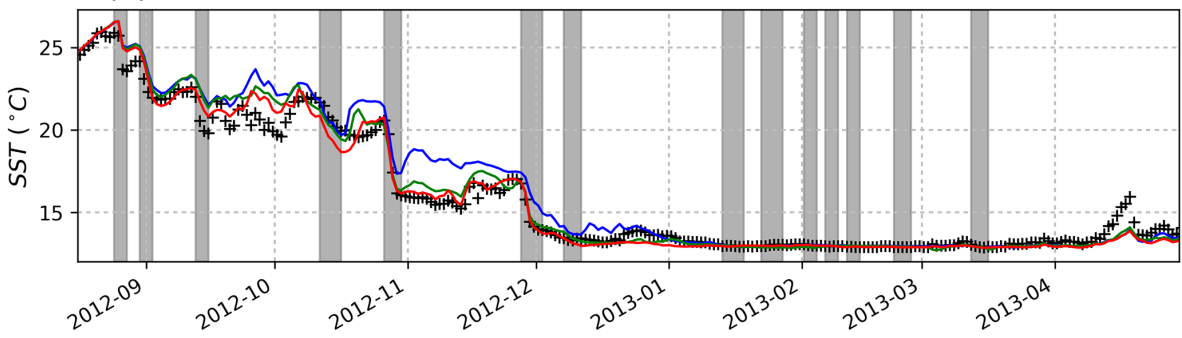

Figure 4. Time series of (a) the $10 \mathrm{~m}$ wind speed, (b) the $2 \mathrm{~m}$ air temperature, (c) the $2 \mathrm{~m}$ air humidity and (d) the sea surface temperature measured at the Lion meteorological buoy (in black) and computed by each simulation (COARE in blue, ANDREAS in green and MOON in red). The grey bars correspond to the strong wind periods (hourly wind speed $>15 \mathrm{~m} \mathrm{~s}^{-1}$ ).

Table 2. Statistics of surface atmospheric and oceanic parameters at the Lion meteorological buoy.

\begin{tabular}{lrcc|rcc|rc|rc}
\hline Exp. & \multicolumn{3}{c|}{ COARE } & \multicolumn{3}{c|}{ ANDREAS } & \multicolumn{3}{|c}{ MOON } \\
\hline Stat. & Bias & rms & $R$ & Bias & rms & $R$ & Bias & rms & $R$ \\
\hline U10M & -0.08 & 2.19 & 0.90 & -0.16 & 2.21 & 0.90 & 0.11 & 2.17 & 0.90 \\
T2M & -0.22 & 1.07 & 0.98 & -0.18 & 1.02 & 0.98 & -0.08 & 0.96 & 0.98 \\
HU2M & 3.24 & 7.02 & 0.85 & 3.45 & 7.23 & 0.85 & 1.15 & 6.17 & 0.85 \\
SST & -0.50 & 1.11 & 0.98 & -0.15 & 0.72 & 0.99 & 0.05 & 0.61 & 0.99 \\
\hline
\end{tabular}

ences between simulations. The largest difference is found for humidity. In particular, it is clear from Fig. 4c that the moisture drops associated with the strong wind episodes are more pronounced in COARE and ANDREAS than in MOON.

The calculated sea surface temperature is remarkably well correlated with the observations for all simulations ( $>0.98$; Table 2). This correlation is mainly due to the representa- tion of the seasonal cycle and to the weak variability of the SST during the winter period when the SST ceases to evolve. The drops of SST associated with the events of Tramontane and Mistral in autumn are well captured by the three simulations. However, there are significant differences between simulations in autumn. In particular, the COARE SSTs appear overestimated (Figs. 4d and 5d). During this period, the Tramontane and Mistral events produce a cooling in response 
(a)

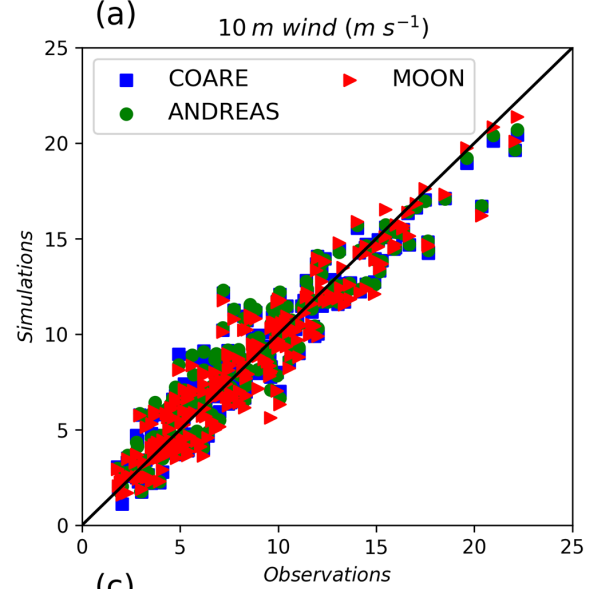

(c) $\quad 2$ Observations 2 air humidity (\%)

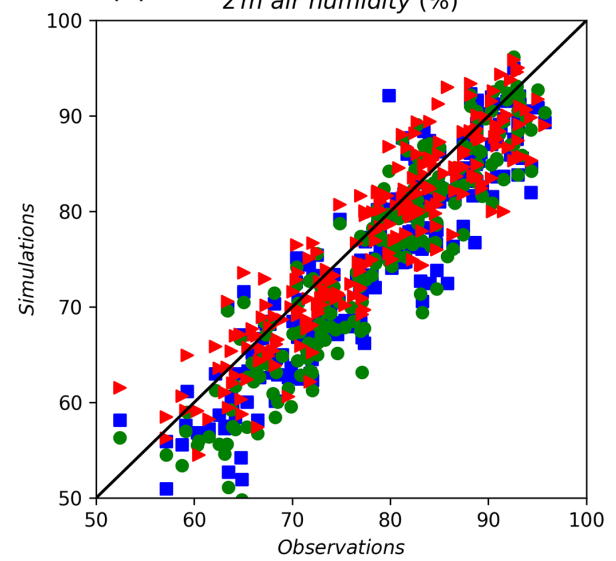

(b)

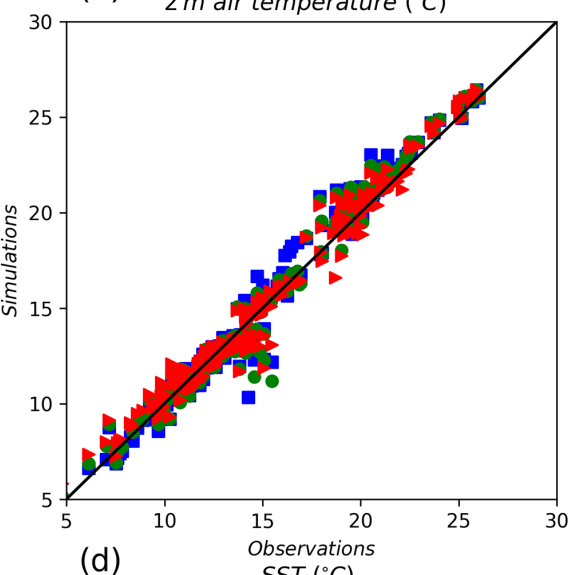

(d)

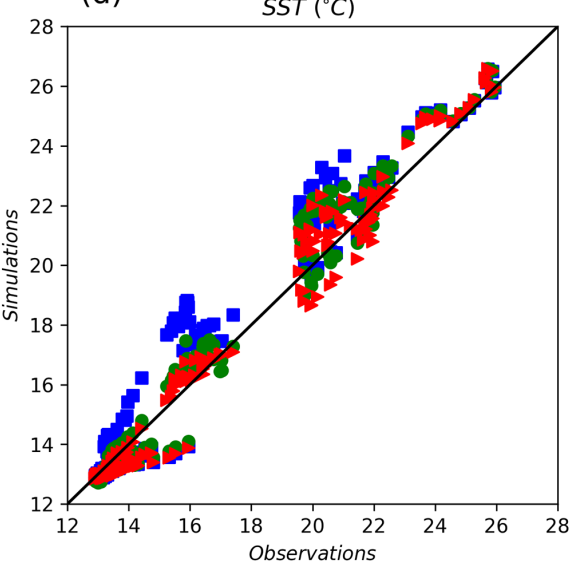

Figure 5. Scatter plots of simulations against observations at the Lion buoy for (a) the $10 \mathrm{~m}$ wind speed, (b) $2 \mathrm{~m}$ air temperature and (c) humidity, and (d) sea surface temperature.

to the enhanced turbulent heat fluxes on the one hand and to the temperature advection associated with the northward displacement of the NBF on the other hand (Estournel et al., 2016a). Integrated during the autumn period, the advection processes in mass budget represent about $40 \%$ compared to local processes. In such conditions, it is clear that a reasoning limited to the local vertical exchanges is insufficient to provide a rigorous analysis of the results. Nevertheless, it can be concluded from Figs. 4 and 5 and Table 2 that in general the results of MOON and ANDREAS appear to agree with the Lion buoy better than the results of COARE do and that MOON slightly outperforms ANDREAS.

\subsubsection{Air-sea fluxes}

The time evolution of the turbulent fluxes computed at the buoy is shown in Fig. 6. Unfortunately, as there was no flux measurement at the buoy, this figure is limited to modelmodel comparison. During the strong wind episodes, all the turbulent fluxes are strongly enhanced and the air-sea exchanges are intensified. As suggested in Fig. 2, the wind stress is very similar for all three simulations (Fig. 6a), while the sensible and latent heat fluxes (Fig. $6 \mathrm{~b}$ and c) can differ significantly from one simulation to another, especially during the strong Mistral and Tramontane wind events. During these events, in accordance with Fig. 2, the strongest sensible and latent heat fluxes are obtained with MOON and the weakest with COARE. ANDREAS produces a sensible heat flux similar to that of MOON and a weaker latent heat flux more similar to that of COARE. For example, on 28 November (corresponding to one of the strongest wind episodes), the daily average latent heat flux reaches $1100 \mathrm{~W} \mathrm{~m}^{-2}$ in MOON versus only $780 \mathrm{~W} \mathrm{~m}^{-2}$ in COARE and ANDREAS. On the same day, the sensible heat flux is $390 \mathrm{~W} \mathrm{~m}^{-2}$ in MOON and ANDREAS compared to only $300 \mathrm{~W} \mathrm{~m}^{-2}$ in COARE.

Furthermore, during autumn, as shown in Fig. 4d, the sea surface temperature evolves differently in each simulation. This is particularly the case for the COARE simulation, which presents significantly warmer SSTs than the other two simulations and than observations. This results in larger turbulent heat fluxes during low wind periods in autumn for the COARE simulation than for ANDREAS and MOON (Fig. 6). 
(a)

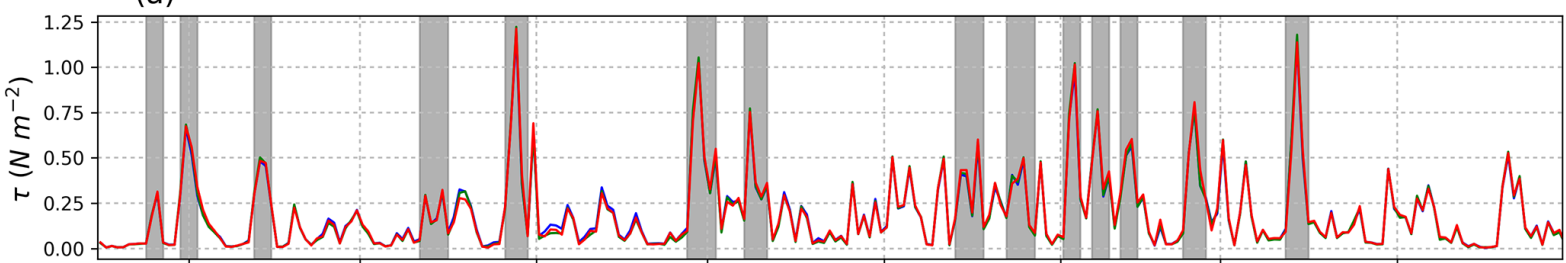

(b)

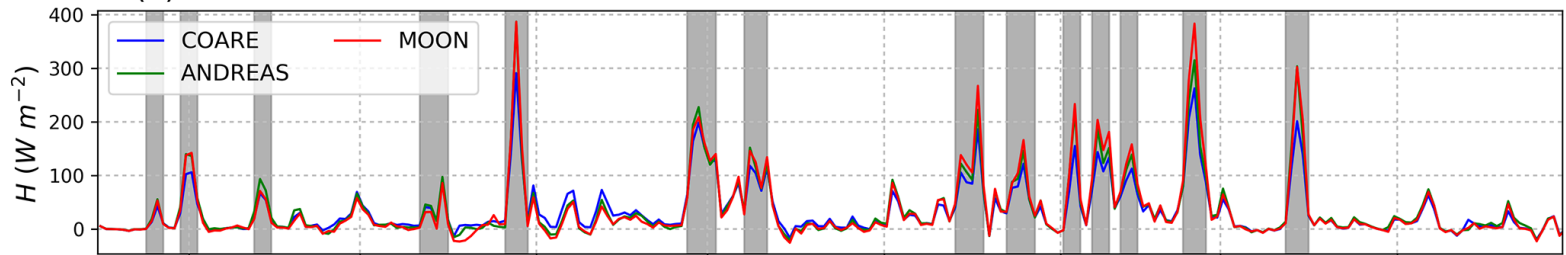

(c)

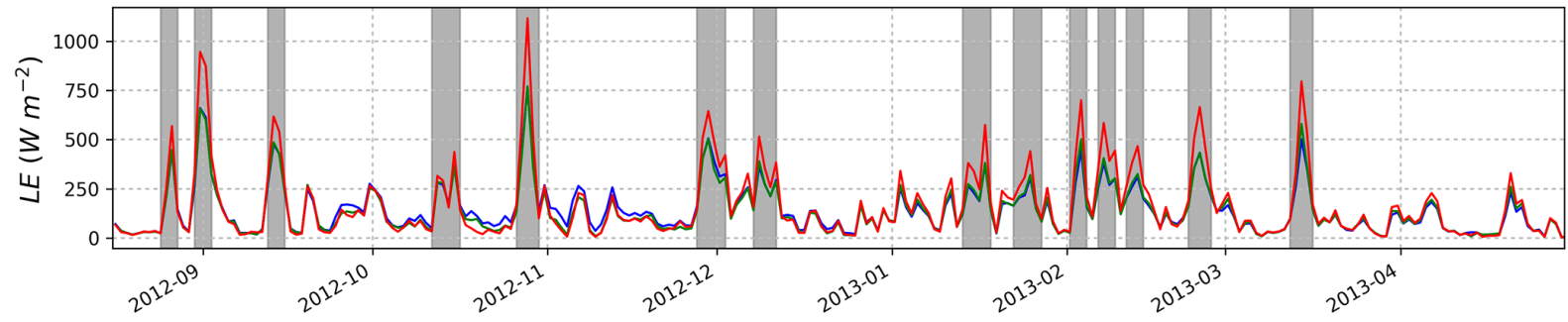

Figure 6. Time series of computed (a) wind stress, (b) sensible heat flux and (c) latent heat flux at the location of the Lion buoy for each simulation (COARE in blue, ANDREAS in green and MOON in red). The grey bars correspond to the strong wind periods (hourly wind speed $\left.>15 \mathrm{~m} \mathrm{~s}^{-1}\right)$.

(a)
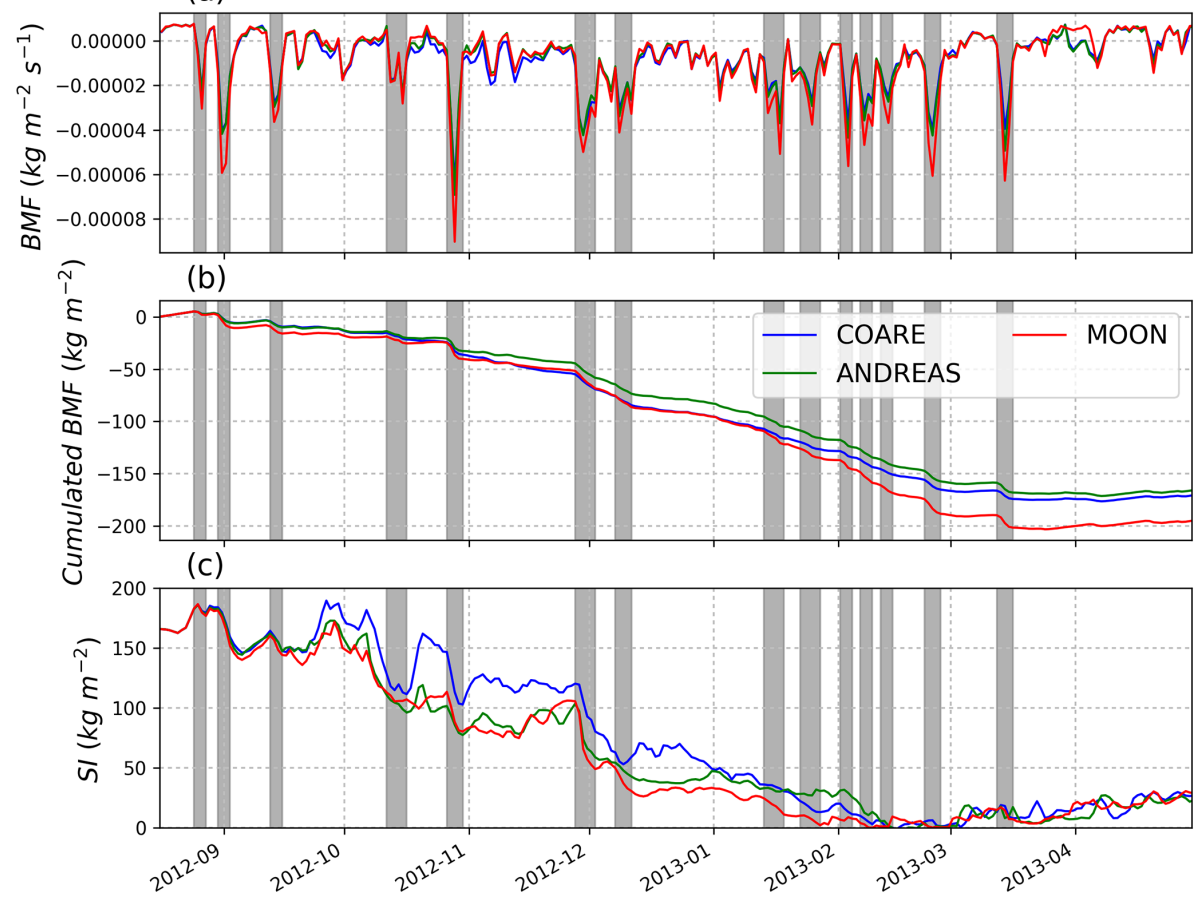

Figure 7. Time series of (a) instantaneous buoyancy mass fluxes, (b) cumulated buoyancy mass fluxes (Eq. 5) and (c) stratification index (Eq. 4) relative to $2000 \mathrm{~m}$ at the Lion buoy computed for each simulation (COARE in blue, ANDREAS in green and MOON in red). The grey bars correspond to the strong wind periods (hourly wind speed $>15 \mathrm{~m} \mathrm{~s}^{-1}$ ). 
To complement the analysis, the radiative fluxes and precipitation, which also contribute to the air-sea exchanges, have been analysed. The results are in good agreement with the observations and do not reveal any significant difference between the simulations; they are not presented here.

In summary, all the simulations generally are in good agreement with the surface parameters observed at the Lion buoy throughout the 8 months considered, although significant punctual differences may appear between the different simulations, especially during the Tramontane and Mistral events. These differences mainly affect the heat and moisture exchanges, whereas the momentum exchanges are very weakly impacted. Although the differences remain fairly weak and as reflected by the statistical analysis, in our coupled system, the MOON parameterization gives the best agreement with the available observations. However, considering the impossibility of directly validating the air-sea fluxes and also the multiple sources of uncertainty in such a complex modelling system (and their possible compensations) it is not clear whether the MOON flux parameterization is better per se or whether it is simply is the most suitable parameterization for our modelling system.

\subsection{Impact of the air-sea exchanges on the oceanic stratification}

\subsubsection{Buoyancy mass fluxes and oceanic stratification}

The air-sea exchanges are now assessed through the buoyancy mass flux (BMF). This flux, directly linked to turbulent fluxes but also to radiative fluxes and precipitation, is formulated as follows:

$\mathrm{BMF}=\alpha \frac{Q_{\text {net }}}{C_{\mathrm{p}}}+\beta \operatorname{SSS} \rho_{0}(E-P)$,

where $\alpha$ is the thermal expansion coefficient in $\mathrm{K}^{-1}, Q_{\text {net }}$ is the net heat flux (sum of the net radiative flux and turbulent heat fluxes) in $\mathrm{W} \mathrm{m}^{-2}, C_{\mathrm{p}}$ is the specific heat capacity in $\mathrm{J} \mathrm{kg}^{-1} \mathrm{~K}^{-1}, \beta$ is the saline contraction coefficient in $\mathrm{psu}^{-1}$, SSS is the surface salinity in psu, $\rho_{0}$ is a reference density in $\mathrm{kg} \mathrm{m}^{-3}, E$ is the evaporation and $P$ is the precipitation in $\mathrm{m} \mathrm{s}^{-1}$. BMF is expressed in $\mathrm{kg} \mathrm{m}^{-2} \mathrm{~s}^{-1}$.

The time evolution of the buoyancy mass flux computed at the Lion buoy and for each simulation is shown in Fig. 7a (instantaneous values) and $7 \mathrm{~b}$ (cumulative values). Its evolution closely follows (with the opposite sign) the evolution of the turbulent fluxes. The maximum buoyancy losses appear during Tramontane and Mistral events, which account for about $70 \%$ of the total buoyancy loss. The simulations can be segmented into three periods: first, the preconditioning period (16 August-15 January) with a decrease in the cumulated buoyancy mass flux and in SST; then, the convective period (15 January-21 March) with a decrease in the cumulated buoyancy mass flux without significant decrease in SST (since the water column is nearly mixed); and, finally, the start of the re-stratification period (21 March30 April) when the buoyancy mass flux starts to increase. As can be seen in Fig. 7b, the buoyancy loss during the preconditioning period is nearly equivalent to the buoyancy loss during the convective period. The largest cumulative buoyancy loss at the end of the simulations is obtained with MOON (195 $\left.\mathrm{kg} \mathrm{m}^{-2}\right)$, followed by COARE $\left(170 \mathrm{~kg} \mathrm{~m}^{-2}\right)$ and ANDREAS $\left(165 \mathrm{~kg} \mathrm{~m}^{-2}\right)$. By the end of the simulations, COARE has produced a slightly larger loss of buoyancy than ANDREAS while turbulent fluxes for the Tramontane and Mistral events are greater in ANDREAS. This is due to the larger buoyancy mass flux during the calm wind periods of the preconditioning phase in COARE.

Figure $7 \mathrm{c}$ shows the time evolution of the stratification index (Eq. 4) relative to the $2000 \mathrm{~m}$ depth at the location of the buoy. At the beginning of the simulations, the stratification is $160 \mathrm{~kg} \mathrm{~m}^{-2}$, i.e. less than the total buoyancy loss produced by any of the simulations, suggesting that in all three simulations, in absence of horizontal advection, the water column could experience full mixing down to a depth of $2000 \mathrm{~m}$ at the buoy location. The decrease of the stratification index with time is not continuous and its evolution is not strictly directly correlated with the evolution the cumulated buoyancy mass flux (as it would be in a one-dimensional system). Even if most of the stratification losses occur mainly during the Tramontane and Mistral, during the weak wind periods, despite the slow decrease of cumulated buoyancy mass flux, the stratification index may increase.

Figure 8 places these local results in a wider context and shows the spatial distribution of the cumulated buoyancy mass fluxes during the whole simulation period, the preconditioning period and the convective period for each simulation. During the whole simulation period, three distinct maxima of buoyancy loss appear: two in the Gulf of Lion, located within the Tramontane and Mistral corridors, and a third one located further south. Whereas the first two stem from local wind maxima, the southern maximum, only present during the preconditioning period, is more related to the warm waters brought over by the seasonal northward displacement of the NBF. When the Tramontane or Mistral blows over this warm patch, the event is associated with strong air-sea temperature gradients and enhanced turbulent heat fluxes. This explains the very strong buoyancy mass-flux losses observed during the autumnal Tramontane and Mistral events at the buoy location (Fig. 7a), which is situated in the vicinity of the frontal zone. This suggests that, during the preconditioning period, the dynamics of the NBF plays a major role in the loss of surface buoyancy in the deep-water zone. Furthermore, the front displacement is modulated by the wind intensity. The increase (decrease) of stratification during the period of weak (strong) winds (Fig. 7c) is due to the lateral advection of light (heavy) water by the northward (southward) displacement of NBF (Estournel et al., 2016a). Because of these horizontal processes and their feedback on the buoyancy mass flux, the three simulations experience differ- 

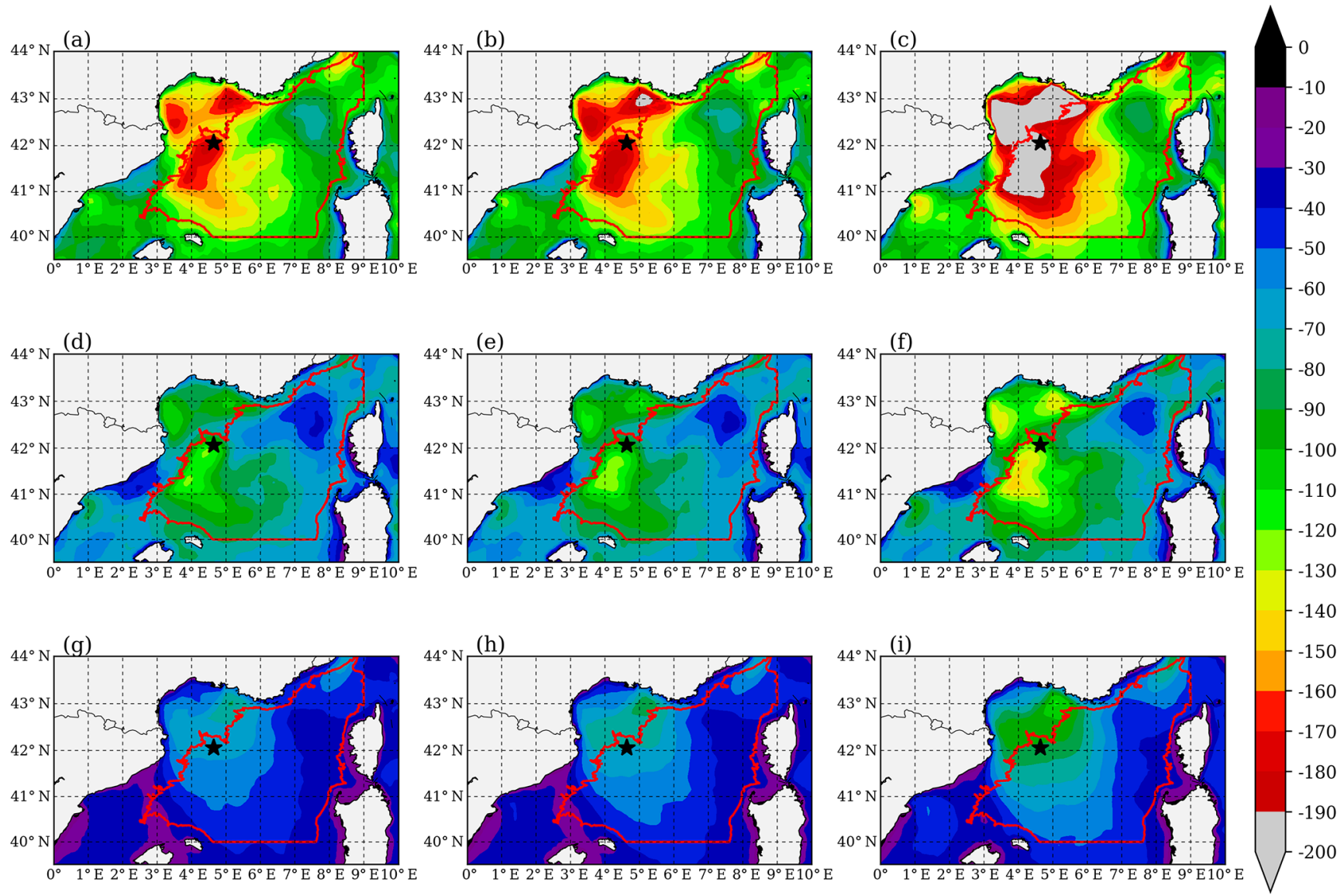

Figure 8. Buoyancy mass fluxes (in $\mathrm{kg} \mathrm{m}^{-2}$ ) (a-c) during the preconditioning and convective periods (16 August 2012 to $21 \mathrm{March}$ ), (df) only during the preconditioning period (16 August 2012 to 15 January 2013) and (g-i) only during the convective period (15 January to 21 March 2013) computed for each simulation: (a, d, g) COARE, (b, e, h) ANDREAS and (c, f, i) MOON. Red line: convective area defined in Sect. 3. Black star: location of the Lion meteorological buoy.

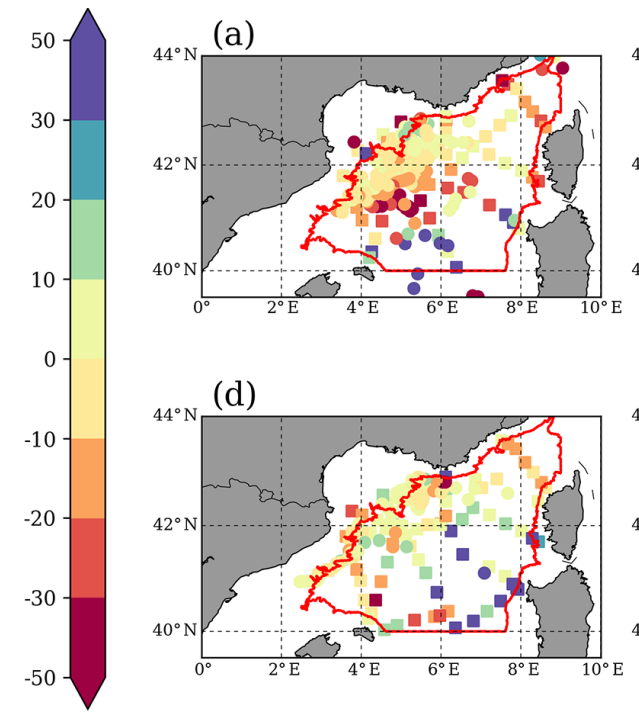

(b)

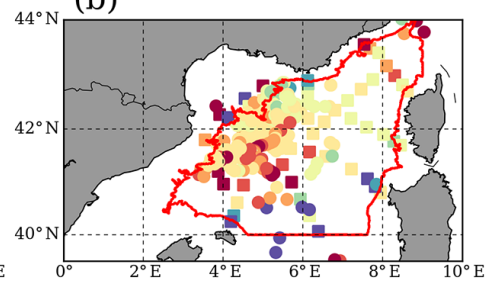

(e)

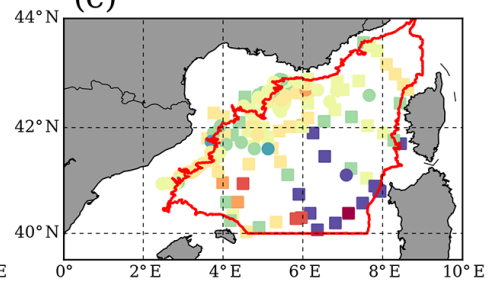

(c)

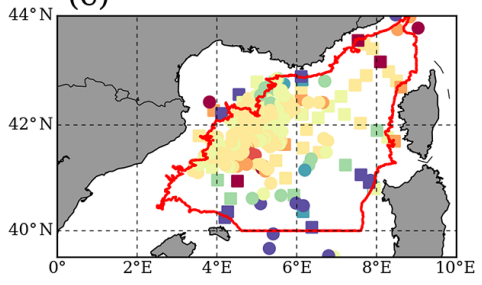

(f)

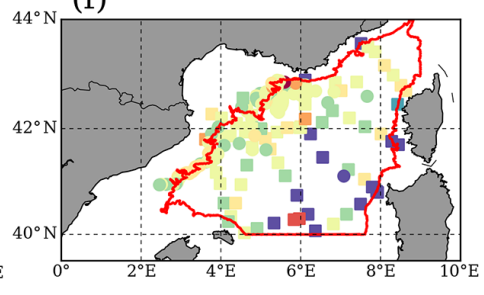

Figure 9. Bias of the stratification index relative to $1000 \mathrm{~m}$ calculated for each simulation - (a, d) COARE, (b, e) ANDREAS and (c, f) MOON - during the (a-c) DEWEX leg 1 cruise and (d-f) DEWEX leg 2 cruise. Red line: convective area defined in Sect. 3. 
ent time evolutions. The large discrepancy seen between the COARE and MOON buoyancy mass fluxes and stratification indices may also result from differences in the NBF progression. In winter, during the convective phase, only the two maxima of the Gulf of Lion remain. In the deep-water zone, as the SST has reached a nearly constant value, there is no significant effect of the SST structures on the buoyancy mass flux. At the Lion buoy, the buoyancy mass flux is not affected by the SST, and the local increase in stratification during the period of weak winds (Fig. 7c) is principally due to the advection of light water into the mixing zone by baroclinic instability (Marshall and Schott, 1999).

The comparison of the three simulations highlights the impact of the surface flux parameterization. In MOON, the buoyancy mass-flux losses are stronger than in COARE and affect a much wider area.

\subsubsection{Validation of oceanic stratification with oceanographic cruises}

To assess the evolution of the oceanic stratification, SIs collocated in space and time with all CTD and ARGO profiles were calculated for each simulation and compared with the corresponding values deduced from the observations. Results were analysed in terms of bias (observations minus simulations). Figure 9 shows the spatial distribution of the SI $(1000 \mathrm{~m})$ bias obtained for each simulation and for the two DEWEX oceanographic cruises (leg 1 in winter 2013 and leg 2 in spring 2013), while Table 3 gives the values of the averaged SI for observations and the SI simulations bias and root mean square error (RMSE) computed in the convective area for different depths (1000, 1500 and $2000 \mathrm{~m}$ ).

During the convective phase (winter 2013), as shown in Fig. 3c and e, an area of mixed profiles (with $\left.\mathrm{SI}(1000 \mathrm{~m})<10 \mathrm{~kg} \mathrm{~m}^{-2}\right)$ induced by the oceanic deep convection is present in the centre of the basin. This area is surrounded by more stratified waters corresponding to the NC to the north and to the NBF to the south. From Fig. 9a-c, it is clear that all the simulations present an excess of stratification in the convective area (negative bias) and an excess of mixing south of the NBF (positive bias). However, it is noteworthy that the $\mathrm{SI}(1000 \mathrm{~m})$ bias is significantly reduced in the MOON simulation (Fig. 9c). The good performance of MOON with respect to the stratification is further confirmed by Table 3: at 1500 and $2000 \mathrm{~m}$, the SI bias reduction obtained with MOON is even more spectacular. During spring 2013, as seen in Fig. 3d and e, the stratification index starts to slowly increase in the convection area. For all simulations, as in winter, the negative $\operatorname{SI}(1000 \mathrm{~m})$ bias is large to the south-east and the water column is too mixed, while in the convection area, the bias is fairly low, especially for the MOON simulation (Fig. 9f). On average (Table 3) the bias is now positive and also greater with MOON than for ANDREAS and COARE. However, this is mainly due to the fact that the large positive biases present in the south of the domain in all the simulations are in ANDREAS and COARE partly compensated by large negative biases found in the centre of the convective area (Fig. 9d-f). The slightly better performance of MOON is confirmed by the RMSEs which are lower for MOON than for COARE and ANDREAS, including for DEWEX leg 2 at 1500 and $2000 \mathrm{~m}$ depths.

In summary, the evolution of stratification is not simply related to the buoyancy mass flux but results from the complex interaction between buoyancy mass fluxes and advective processes. In this study, the MOON simulation significantly reduces the negative bias of the stratification, in the convection area, during the convective and re-stratification periods, again indirectly suggesting that the air-sea fluxes are most realistic in the MOON simulation.

\subsection{Impact on the air-sea exchanges on the deep-water formation}

In this section, observations provided by the Lion buoy and the DEWEX cruises are compared with the results of the different simulations in terms of mixed patch, timing of convective process and volume of deep dense water formed.

\subsubsection{Mixed patch}

The spatial distribution of the convection is first examined. Figure 10 shows the position of the stratified and mixed CTD and ARGO profiles and the extent of the mixed patch calculated by the model for the different simulations. The mixed patch is defined here as the grid points where the stratification index relative to $1000 \mathrm{~m}$ (or $2000 \mathrm{~m}$ ) reaches zero at least once during the winter. In other words, this corresponds to the area where deep convection reaches the $1000 \mathrm{~m}$ (or $2000 \mathrm{~m}$ ) depth. The CTD and ARGO profiles indicate that deep convection occurs between 41 and $43^{\circ} \mathrm{N}$, and between 3.5 and $6.5^{\circ} \mathrm{E}$. Obviously, the CTD and ARGO profiles only show a partial view of the mixed patch as they are punctual observations, whereas the simulated mixed patch corresponds to the area where deep convection occurred at least once during winter. The deep convection zone at $1000 \mathrm{~m}$ clearly appears in all the simulations but its eastern (and to a lesser extent, southern) extension varies. The COARE and MOON simulations lead to the smallest and the largest mixed patch, respectively. However, the observed profiles do not allow us to conclude on the most realistic extension at $1000 \mathrm{~m}$. The deep convection zone at $2000 \mathrm{~m}$ is much smaller than at $1000 \mathrm{~m}$, but for this depth, observations clearly indicate that the extent of the mixed patch is better depicted by MOON than by COARE or ANDREAS.

\subsubsection{Timing of convective process}

The development of deep convection is examined using the observations produced by the LION mooring positioned in the centre of the deep-water zone. Figure 11 shows the time evolution of the observed and simulated sea water density 
Table 3. Number of CTD-ARGO observed profiles, observations averaged, simulations bias and RMSE averaged, for SI $\left(\mathrm{kg} \mathrm{m}^{-2}\right)$ at 1000 , 1500 and $2000 \mathrm{~m}$ for DEWEX oceanographic cruises.

\begin{tabular}{lrrrrr}
\hline $\begin{array}{r}\text { Number of profiles } \\
\text { CTD-ARGO }\end{array}$ & $\begin{array}{r}\text { SI-averaged } \\
\text { observations }\end{array}$ & $\begin{array}{r}\text { COARE } \\
\text { bias, RMSE }\end{array}$ & $\begin{array}{r}\text { ANDREAS } \\
\text { bias, RMSE }\end{array}$ & $\begin{array}{r}\text { MOON } \\
\text { bias, RMSE }\end{array}$ \\
\hline DEWEX leg 1 & & & & & \\
\hline $1000 \mathrm{~m}$ & $62-230$ & 13.8 & $-4.9,19.5$ & $-3.8,18.4$ & $1.8,16.6$ \\
$1500 \mathrm{~m}$ & $56-202$ & 12.6 & $-7.4,19.0$ & $-5.7,17.5$ & $-0.4,14.9$ \\
$2000 \mathrm{~m}$ & $48-29$ & 22.0 & $-9.2,24.0$ & $-6.0,22.5$ & $0.9,22.8$ \\
\hline DEWEX leg 2 & & & & & \\
\hline $1000 \mathrm{~m}$ & $78-103$ & 27.0 & $4.2,19.4$ & $6.6,19.0$ & $9.1,20.0$ \\
$1500 \mathrm{~m}$ & $72-88$ & 31.2 & $2.9,19.5$ & $6.0,19.5$ & $7.4,19.2$ \\
$2000 \mathrm{~m}$ & $60-7$ & 42.1 & $3.6,26.7$ & $4.5,26.5$ & $7.4,23.5$ \\
\hline
\end{tabular}

(a)

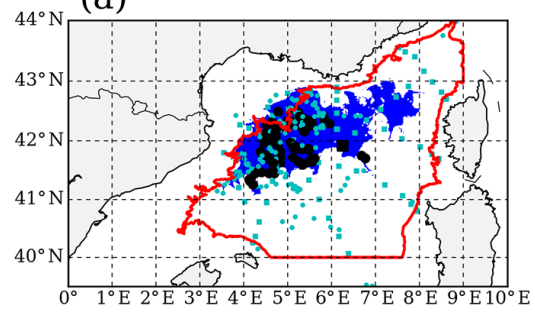

(b)

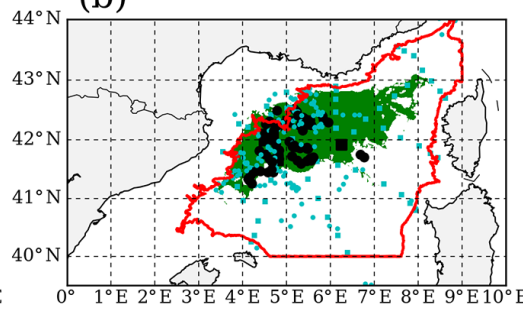

(c)

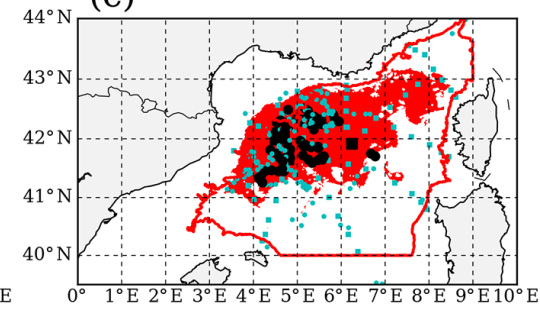

(d)

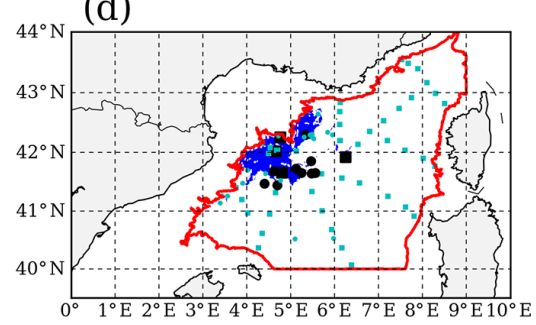

(e)

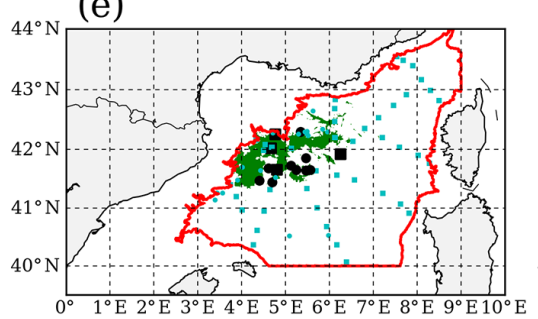

(f)

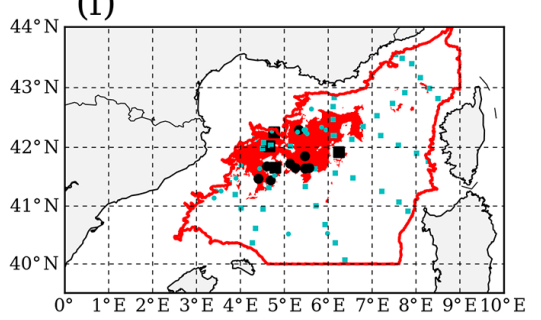

Figure 10. Coloured areas: extent of mixed patch zone computed for each simulation: (a, d) COARE, (b, e) ANDREAS and (c, f) MOON. The mixed patch is defined as the area where the stratification index, (a-c) at $1000 \mathrm{~m}$ and $(\mathbf{d}-\mathbf{f})$ at $2000 \mathrm{~m}$, reaches 0 during simulation. Black squares correspond to the position of the CTD and ARGO mixed profiles: (a-c) SI $(1000)=0$ and $(\mathbf{d}-\mathbf{f}) \operatorname{SI}(2000)=0$. Cyan points show the position of the CTD and ARGO stratified profiles: (a-c) SI(1000) $>0$ and (d-f) SI(2000) > 0. Red line: convective area defined in Sect. 3.

at this point. During the preconditioning period, the surface density anomaly is less than $29.0 \mathrm{~kg} \mathrm{~m}^{-3}$ and the bottom density anomaly is $29.11 \mathrm{~kg} \mathrm{~m}^{-3}$. In the observations, the mixing reaches the first upper level of the LION mooring $(150 \mathrm{~m})$ in mid-January, and the first complete mixing of the water column is achieved at the beginning of February. All the simulations produce deep convection but with different timing and intensity. In the COARE and ANDREAS simulations, complete mixing occurs too late (after the second of the Mistral and Tramontane events of February), while for the MOON simulation, the process occurs too early (after the second of the Mistral and Tramontane events of January). After the complete mixing, a sequence of Tramontane and Mistral events led to the densification of the water column (to a density between 29.12 and $29.13 \mathrm{~kg} \mathrm{~m}^{-3}$ ). This densification in February is represented by all simulations. However, it is too weak in COARE and ANDREAS. Finally, at the beginning of March, a period of weak wind allows surface re-stratification. The last of the strong Tramontane and Mistral events, around 15 March, destroys this re-stratification and again leads to the full mixing of the water column and to an increase of the seawater density up to $29.12 \mathrm{~kg} \mathrm{~m}^{-3}$. This mixing event is not well represented by COARE and ANDREAS. Overall, despite the too-early full mixing, the MOON simulation gives the best representation of the deep convection at the LION mooring and correctly captures its three densification events. 


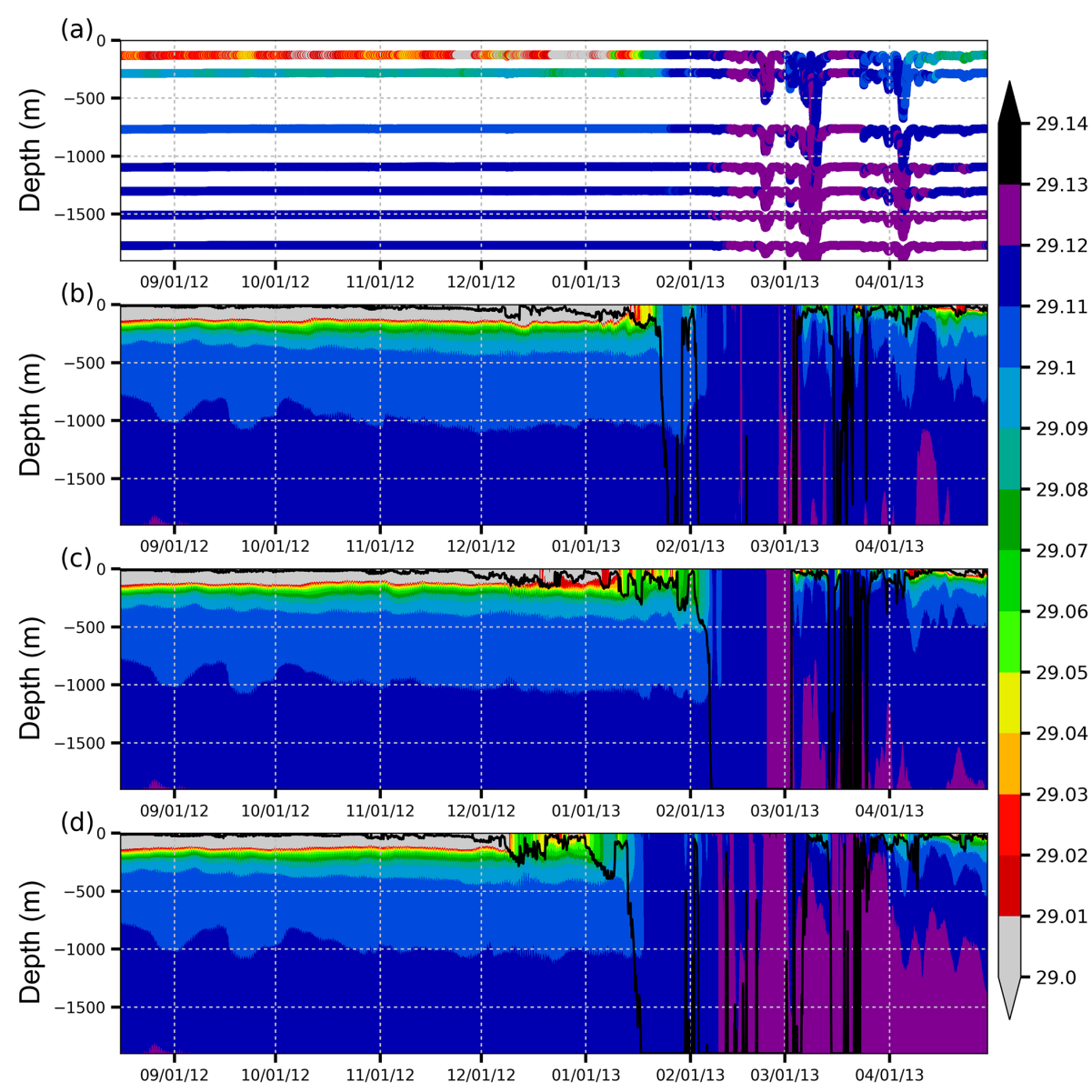

Figure 11. Time series of 0-2000 m sea water density (a) observed at the LION mooring and computed for each simulation (b) COARE, (c) ANDREAS and (d) MOON at the LION mooring location. The black line correspond to mixed layer depth (computed with a density criterion of $0.01 \mathrm{~kg} \mathrm{~m}^{3}$ ). Dates are indicated in $\mathrm{mm} / \mathrm{dd} / \mathrm{yyyy}$ format.

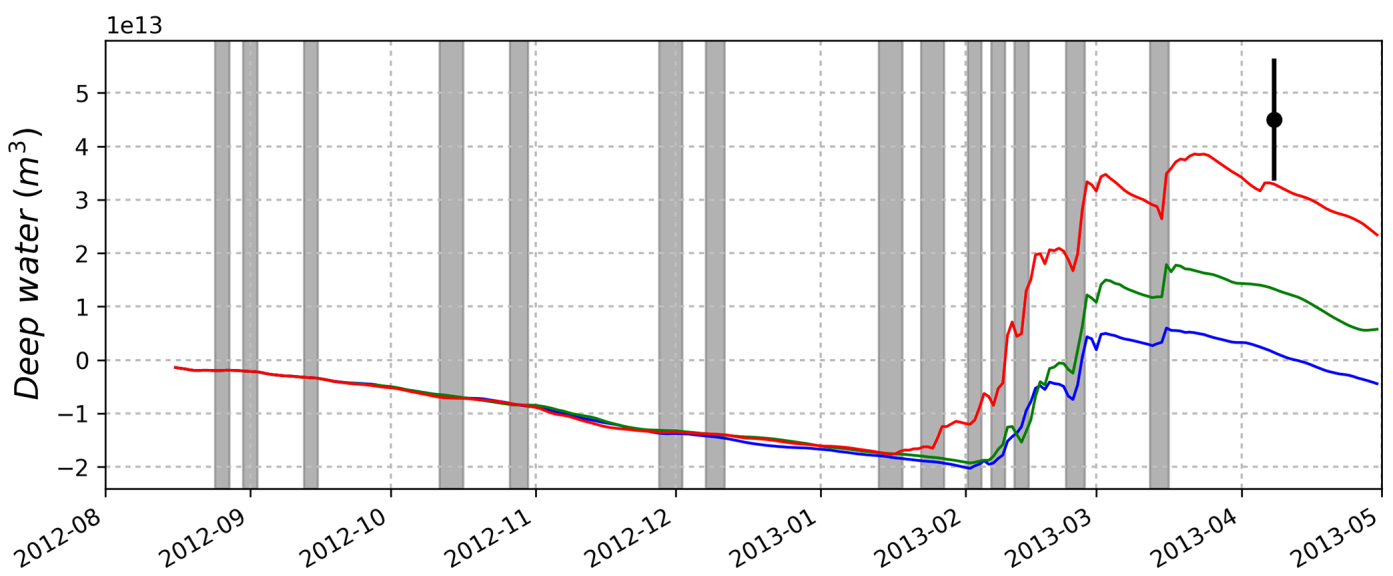

Figure 12. Time series of dense water volume $\left(\mathrm{m}^{3}\right)$ formed from 8 January 2012 for sea water density up to $29.11 \mathrm{~kg} \mathrm{~m}^{-3}$ computed for each simulation (COARE in blue, ANDREAS in green and MOON in red) in the convection area (as defined in Sect. 3). The black dot and error bar correspond to the dense water formation volume estimated from the observations by Waldman et al. (2016b) for the same density thresholds. The grey bars correspond to the strong wind periods (hourly wind speed $>15 \mathrm{~m} \mathrm{~s}^{-1}$ ). 


\subsubsection{Volume of deep water}

The volume of the water mass created by deep convection is evaluated using the method proposed by Waldman et al. (2016b) for the same area and same period. Figure 12 shows the time evolution of the dense water formation rate computed in the simulations and estimated by Waldman et al. (2016b) with its error bar. During autumn, the volume decreases slowly, whatever the simulation. This decrease is due to the dense water advection outside the study zone. Then, in winter, it increases rapidly, especially during the Tramontane and Mistral events, with the development of deep convection. After the convective events, the dense water volume decreases again, due to the re-stratification and export processes. The timing of deep-water formation and the volume created are very different according to the simulations. The timing of deep-water formation is the same as that discussed for the LION mooring. The deep-water volume created depends on the timing, spatial extent and intensity of deep convection processes. The COARE, ANDREAS and MOON simulations produce, respectively, $0.3 \times 10^{13}, 1.5 \times$ $10^{13}$ and $3.4 \times 10^{13} \mathrm{~m}^{3}$ between summer 2012 and spring 2013. For the three simulations, the amount of dense water formed is lower than that calculated from the observations $\left(4.5( \pm 1.1) \times 10^{13} \mathrm{~m}^{3}\right)$. However, the most realistic volume is obtained with MOON. Finally, the new dense water product during the increasing phases in the dense water volume time series is $3.58 \times 10^{13}, 4.88 \times 10^{13}$ and $8.02 \times 10^{13} \mathrm{~m}^{3}$, respectively, for COARE, ANDREAS and MOON simulation. The differences between the simulations highlight the great sensitivity of deep-water formation to turbulent flux parameterization.

\section{Conclusions}

This study focused on assessing the ability of a regional ocean-atmosphere coupled system, based on the SYMPHONIE, SURFEX and MESONH models, to correctly represent ocean convection and deep-water formation in the NWMS. Several realistic simulations were carried out over a period of 8 months, from summer 2012 to spring 2013, and were used to investigate the sensitivity of the system to the parameterization of turbulent fluxes.

First, this study shows the ability of the air-sea coupled system to reproduce the evolution of the ocean and the atmosphere for several months by relying only on realistic initial and boundary conditions and without resorting to data assimilation or nudging. For all simulations, a good correlation is obtained between the observed and computed surface parameters at the Lion buoy. During the Tramontane and Mistral events, the turbulent heat fluxes differ significantly from one simulation to another, directly impacting the atmospheric and oceanic surface parameters. In a previous study devoted to the same case study, Rainaud et al. (2016) un- derlined the difficulty of reproducing air surface temperature and moisture during the Mistral and Tramontane events and advocated the use of an air-sea coupled model and a purposely adjusted turbulent flux parameterization. In addition to air surface temperature and moisture, sea surface temperature is also strongly sensitive to the turbulent flux parameterizations. Our results also suggest that coupling plays a key role during the autumn storms when the rapid drops of SST reduce the turbulent heat fluxes. In winter, the impact of the coupling is likely to be weaker since the SST does not vary much anymore. Among the three parameterizations, we found that MOON (i.e. the parameterization yielding the strongest heat turbulent fluxes) significantly reduced the bias between the observed and computed surface parameters. Unfortunately, due to the lack of flux measurements at the buoy, it was not possible to validate the computed turbulent surface fluxes directly.

Then, the buoyancy mass flux was calculated and compared to the evolution of the stratification for each simulation. The stratification evolution is directly impacted by the buoyancy mass-flux loss but there is no strict correlation between stratification and buoyancy mass flux. As already shown in Estournel et al. (2016a), this confirms the importance of the advective processes on the evolution of the stratification in the deep-water area. Moreover, these advective processes also directly impact the surface buoyancy mass fluxes, particularly during preconditioning period, when the position and dynamics of the North Balearic Front clearly affect these fluxes. This interaction between the buoyancy mass fluxes and the advective processes is clearly an air-sea coupled process, which deserves to be analysed in greater depth. In terms of stratification, the use of MOON also led to a general reduction of the bias between observed and computed parameters.

Finally, the timing and the spatial extent of the convection process are very sensitive to the flux parameterization. This impacts the volume of the newly formed deep water, which varies from $3.58 \times 10^{13} \mathrm{~m}^{-3}$ (with COARE) to $8.02 \times 10^{13} \mathrm{~m}^{-3}$ (with MOON), i.e. by a factor of 2.2. For the same case study, Léger et al. (2016) studied the sensitivity to initial conditions and found a factor of 4.4 between two very different sets of initial conditions. Our results suggest that the sensitivity of the deep-water formation process in NWMS to atmospheric forcing may be of the same order of magnitude. Here again, in spite of convection being triggered too early and the volume of dense water formed being slightly underestimated, MOON appears to give the most satisfactory results.

However, this conclusion regarding the good performance of the MOON flux parameterization needs to be further consolidated.

First, the present results were obtained with a coupled system. They could probably be different with uncoupled simulations. In air-sea coupled simulations, the interactive evolution of ocean and atmosphere influences the turbulent 
heat fluxes, which themselves modify the atmospheric and oceanic surface fields involved in the flux calculation. In statically unstable Mistral and Tramontane conditions, if the sensible (or latent) heat flux increases, the vertical temperature (or humidity) gradient is reduced, which in turn limits the increase in the sensible (latent) heat flux. It is likely that these feedback loop effects tend to limit the discrepancies between the different parameterizations. The results of partial and preliminary uncoupled simulations (not shown) suggest that these discrepancies could be larger than in the coupled simulations. It would be therefore of great interest to disentangle the effect of the flux formulation from the effect of the air-sea coupling and to check whether the MOON parameterization still improves the results in uncoupled conditions. However, it is not straightforward to isolate the coupling effect in a clean and rigorous way. This requires a series of carefully designed experiments in which the current coupled system is downgraded step-by-step into an uncoupled system until it exactly mimics the behaviour of the atmospheric and ocean models in their stand-alone configuration. In our current system, this type of study is hampered by the fact that the surface fluxes are computed on the atmospheric grid, i.e. at a coarser resolution that the one used by the ocean model.

The differences in resolution between the atmospheric and ocean models (10 and $1 \mathrm{~km}$, respectively), though partly justified by scale considerations, are also a debatable question. A further development will thus investigate the sensitivity to the resolution of the atmospheric model. In the present configuration, the atmospheric model does not have the possibility of representing scales fully adjusted to those of the oceanic model. In particular, with a $10 \mathrm{~km}$ resolution, the local maxima and horizontal gradients of the surface parameters are probably too smooth, which may affect the air-sea interactions especially in the vicinity of the oceanic front (Small et al., 2008) and could also modify the response of the coupled system to the different parameterizations.

In addition, the role of the waves necessitates further investigation. In our study, the waves are not considered in COARE and MOON, and only indirectly accounted for in ANDREAS. In ANDREAS, the depth of the spray layer is computed as a function of the significant wave height (Andreas et al., 1995). The latter is rather roughly estimated from a simplified parameterization based on wind speed (Andreas and Wang, 2007). Similar crude relationships are used in COARE3.0 for the wave height and wave period when the wave option is turned on. Another envisaged development will couple the current system with a wave model (Michaud et al., 2012 and the references cited therein) and revisit the results obtained with the ANDREAS and COARE3.0 parameterizations.
Data availability. The Argo data were collected and made freely available by the CORIOLIS project (https://doi.org/10.17882/42182). The CTD MOOSE data were collected and made freely available by the MOOSE network (https://doi.org/10.17600/12020030). The CTD DOWEX, DEWEX leg 1 and DEWEX leg 2 data were collected and made freely available by the MERMEX project (DOWEX: https://doi.org/10.17600/12450170, DEWEX leg 1: https://doi.org/10.17600/13020010 and DEWEX leg 2: https://doi.org/10.17600/13020030). The LION mooring data were collected and made freely available by the MOOSE network (https://doi.org/10.17882/44411).

Competing interests. The authors declare that they have no conflict of interest.

Acknowledgements. This work is a contribution to the MISTRALS/HyMeX programme through the ASICS-MED (ANR12-BS06-0003) project funded by the French National Agency for Research (ANR). Data were obtained from the HyMeX programme, sponsored by grants from MISTRALS/HyMeX and Météo-France. The authors acknowledge the international ARGO programme, the LEFE/GMMC programme and the French NAOS project for supporting the deployment of profilers. We acknowledge the crews of R/V Suroit and Tethys II, and the scientists involved in the different cruises mentioned in this paper. Numerical simulations were performed using HPC resources from CALMIP (CALcul en MIdi-Pyrénées, projects 1247, 09115 and 1325) and GENCI (Grand Equipement National de Calcul Intensif, project 010569).

Edited by: Simon Josey

Reviewed by: two anonymous referees

\section{References}

Andreas, E. L.: Approximation formulas for the microphysical properties of saline droplets, Atmos. Res., 75, 323-345, https://doi.org/10.1016/j.atmosres.2005.02.001, 2005.

Andreas, E. L. and Wang, S.: Predicting significant wave height off the northeast coast of the United States, Ocean Eng., 34, 13281335, https://doi.org/10.1016/j.oceaneng.2006.08.004 2007.

Andreas, E. L., Edson, J. B., Monahan, E. C., Rouault, M. P., and Smith, S. D.: The spray contribution to net evaporation from the sea: A review of recent progress, Bound.-Lay. Meteorol., 72, 352, https://doi.org/10.1007/BF00712389, 1995.

Andreas, E. L., Mahrt, L., and Vickers, D.: An improved bulk air-sea surface flux algorithm, including spraymediated transfer, Q. J. Roy. Meteor. Soc., 141, 642-654, https://doi.org/10.1002/qj.2424, 2015.

Bechtold, P., Bazile, E., Guichard, F., Mascart, P., and Richard, E.: A mass-flux convection scheme for regional and global models, Q. J. Roy. Meteor. Soc., 127, 869-886, 2001.

Bentsen, M., Evensen, G., Drange, H., and Jenkins, A. D.: Coordinate Transformation on a Sphere Using Conformal Mapping, Mon. Weather Rev., 
127, 2733-2740, https://doi.org/10.1175/15200493(1999)127<2733:CTOASU>2.0.CO;2, 1999.

Buongiorno Nardelli, B., Tronconi, C., Pisano, A., and Santoleri, R.: High and Ultra-High resolution processing of satellite Sea Surface Temperature data over Southern European Seas in the framework of MyOcean project, Remote Sens. Environ., 129, 116, https://doi.org/10.1016/j.rse.2012.10.012, 2013.

Caniaux, G., Redelsperger, J.-L., and Lafore, J.-P.: A Numerical Study of the Stratiform Region of a Fast-Moving Squall Line, Part I: General Description and Water and Heat Budgets, J. Atmos. Sci., 51, 2046-2074, https://doi.org/10.1175/15200469(1994)051<2046:ANSOTS>2.0.CO;2, 1994.

Charnock, H.: Wind stress on a water surface, Q. J. Roy. Meteor. Soc., 81, 639-640, https://doi.org/10.1002/qj.49708135027, 1955.

Craig, A., Valcke, S., and Coquart, L.: Development and performance of a new version of the OASIS coupler, OASIS3-MCT_3.0, Geosci. Model Dev., 10, 3297-3308, https://doi.org/10.5194/gmd-10-3297-2017, 2017.

Cuxart, J., Bougeault, P., and Redelsperger, J.-L.: A turbulence scheme allowing for mesoscale and largeeddy simulations, Q. J. Roy. Meteor. Soc., 126, 1-30, https://doi.org/10.1002/qj.49712656202, 2000.

Deardorff, J. W., Willis, G. E., and Lilly, D. K.: Laboratory investigation of non-steady penetrative convection, J. Fluid Mech., 35, 7-31, 1969.

Donlon, C. J., Martin, M., Stark, J., Roberts-Jones, J., Fiedler, E., and Wimmer, W.: The Operational Sea Surface Temperature and Sea Ice Analysis (OSTIA) system, Remote Sens. Environ., 116, 140-158, https://doi.org/10.1016/j.rse.2010.10.017, 2012.

Drobinski, P., Ducrocq, V., Alpert, P., Anagnostou, E., Béranger, K., Borga, M., Braud, I., Chanzy, A., Davolio, S., Delrieu, G., Estournel, C., Boubrahmi, N. F., Font, J., Grubišič, V., Gualdi, S., Homar, V., Ivančan-Picek, B., Kottmeier, C., Kotroni, V., Lagouvardos, K., Lionello, P., Llasat, M. C., Ludwig, W., Lutoff, C., Mariotti, A., Richard, E., Romero, R., Rotunno, R., Roussot, O., Ruin, I., Somot, S., Taupier-Letage, I., Tintore, J., Uijlenhoet, R., and Wernli, H.: HyMeX: A 10-Year Multidisciplinary Program on the Mediterranean Water Cycle, B. Am. Meteorol. Soc., 95, 1063-1082, https://doi.org/10.1175/BAMS-D-12$00242.1,2013$.

Ducrocq, V., Braud, I., Davolio, S., Ferretti, R., Flamant, C., Jansa, A., Kalthoff, N., Richard, E., Taupier-Letage, I., Ayral, P.-A., Belamari, S., Berne, A., Borga, M., Boudevillain, B., Bock, O., Boichard, J.-L., Bouin, M.-N., Bousquet, O., Bouvier, C., Chiggiato, J., Cimini, D., Corsmeier, U., Coppola, L., Cocquerez, P., Defer, E., Delanoë, J., Di Girolamo, P., Doerenbecher, A., Drobinski, P., Dufournet, Y., Fourrié, N., Gourley, J. J., Labatut, L., Lambert, D., Le Coz, J., Marzano, F. S., Molinié, G., Montani, A., Nord, G., Nuret, M., Ramage, K., Rison, W., Roussot, O., Said, F., Schwarzenboeck, A., Testor, P., Van Baelen, J., Vincendon, B., Aran, M., and Tamayo, J.: HyMeX-SOP1: The Field Campaign Dedicated to Heavy Precipitation and Flash Flooding in the Northwestern Mediterranean, B. Am. Meteorol. Soc., 95, 1083-1100, https://doi.org/10.1175/BAMS-D-1200244.1, 2013.

Estournel, C., Auclair, F., Lux, M., Nguyen, C., and Marsaleix, P.: "Scale oriented" embedded modeling of the North-Western
Mediterranean in the frame of MFSTEP, Ocean Sci., 5, 73-90, https://doi.org/10.5194/os-5-73-2009, 2009.

Estournel, C., Testor, P., Damien, P., D’Ortenzio, F., Marsaleix, P., Conan, P., Kessouri, F., Durrieu de Madron, X., Coppola, L., Lellouche, J.-M., Belamari, S., Mortier, L., Ulses, C., Bouin, M.-N., and Prieur, L.: High resolution modeling of dense water formation in the north-western Mediterranean during winter 2012-2013: Processes and budget, J. Geophys. Res.-Oceans, 121, 5367-5392, https://doi.org/10.1002/2016JC011935, 2016 .

Estournel, C., Testor, P., Taupier-Letage, I., et al.: HyMeX-SOP2 The Field Campaign Dedicated to Dense Water Formation in the Northwestern Mediterranean, Oceanography, 29, 196-206, 2016 b.

Fairall, C. W., Bradley, E. F., Rogers, D. P., Edson, J. B., and Young, G. S.: Bulk parameterization of air-sea fluxes for tropical oceanglobal atmosphere coupled-ocean atmosphere response experiment, J. Geophys. Res.-Oceans, 101, 3747-3764, 1996.

Fairall, C. W., Bradley, E. F., Hare, J. E., Grachev, A. A., and Edson, J. B.: Bulk Parameterization of Air-Sea Fluxes: Updates and Verification for the COARE Algorithm, J. Climate, 16, 571-591, https://doi.org/10.1175/15200442(2003)016<0571:BPOASF>2.0.CO;2, 2003.

Flamant, C.: Alpine lee cyclogenesis influence on air-sea heat exchanges and marine atmospheric boundary layer thermodynamics over the western Mediterranean during a Tramontane/Mistral event, J. Geophys. Res.-Oceans, 108, 8057, https://doi.org/10.1029/2001JC001040, 2003.

Foken, T.: 50 Years of the Monin-Obukhov Similarity Theory, Bound.-Lay. Meteorol., 119, 431-447, https://doi.org/10.1007/s10546-006-9048-6, 2006.

Fouquart, Y. and Bonnel, B.: Computations of solar heating of the earth's atmosphere - A new parameterization, Beitraege zur Physik der Atmosphaere, 53, 35-62, 1980.

Gaspar, P., Grégoris, Y., and Lefevre, J.-M.: A simple eddy kinetic energy model for simulations of the oceanic vertical mixing: Tests at station Papa and long-term upper ocean study site, J. Geophys. Res.-Oceans, 95, 16179-16193, https://doi.org/10.1029/JC095iC09p16179, 1990.

Hauser, D., Branger, H., Bouffies-Cloché, S., Despiau, S., Drennan, W. M., Dupuis, H., Durand, P., Durrieu de Madron, X., Estournel, C., Eymard, L., Flamant, C., Graber, H. C., Guérin, C., Kahma, K., Lachaud, G., Lefèvre, J.-M., Pelon, J., Pettersson, H., Piguet, B., Queffeulou, P., Tailliez, D., Tournadre, J., and Weill, A.: The FETCH experiment: An overview, J. Geophys. Res.-Oceans, 108, 8053, https://doi.org/10.1029/2001JC001202, 2003.

Herrmann, M., Somot, S., Sevault, F., Estournel, C., and Déqué, M.: Modeling the deep convection in the northwestern Mediterranean Sea using an eddy-permitting and an eddy-resolving model: Case study of winter 1986-1987, J. Geophys. Res.-Oceans, 113, C04011, https://doi.org/10.1029/2006JC003991, 2008.

Herrmann, M., Sevault, F., Beuvier, J., and Somot, S.: What induced the exceptional 2005 convection event in the northwestern Mediterranean basin? Answers from a modeling study, J. Geophys. Res.-Oceans, 115, C12051, https://doi.org/10.1029/2010JC006162, 2010.

Herrmann, M. J. and Somot, S.: Relevance of ERA40 dynamical downscaling for modeling deep convection in 
the Mediterranean Sea, Geophys. Res. Lett., 35, L04607, https://doi.org/10.1029/2007GL032442, 2008.

Houpert, L., Durrieu de Madron, X., Testor, P., Bosse, A., D’Ortenzio, F., Bouin, M., Dausse, D., Le Goff, H., Kunesch, S., Labaste, M., Coppola, L., Mortier, L., and Raimbault, P.: Observations of open-ocean deep convection in the northwestern Mediterranean Sea: Seasonal and interannual variability of mixing and deep water masses for the 20072013 period, J. Geophys. Res.-Oceans, 151, 8139-8171, https://doi.org/10.1002/2016JC011857, 2016.

Kurihara, Y., Tuleya, R. E., and Bender, M. A.: The GFDL hurricane prediction system and its performance in the 1995 hurricane season, Mon. Weather Rev., 126, 1306-1322, https://doi.org/10.1175/15200493(1998)126<1306:TGHPSA>2.0.CO;2, 1998.

Lafore, J. P., Stein, J., Asencio, N., Bougeault, P., Ducrocq, V., Duron, J., Fischer, C., Héreil, P., Mascart, P., Masson, V., Pinty, J. P., Redelsperger, J. L., Richard, E., and Vilà-Guerau de Arellano, J.: The Meso-NH Atmospheric Simulation System, Part I: adiabatic formulation and control simulations, Ann. Geophys., 16, 90-109, https://doi.org/10.1007/s00585-997-0090-6, 1997.

Lebeaupin Brossier, C. and Drobinski, P.: Numerical highresolution air-sea coupling over the Gulf of Lions during two tramontane/mistral events, J. Geophys. Res.-Atmos., 114, D10110, https://doi.org/10.1029/2008JD011601, d10110, 2009.

Lebeaupin Brossier, C., Arsouze, T., Béranger, K., Bouin, M.N., Bresson, E., Ducrocq, V., Giordani, H., Nuret, M., Rainaud, R., and Taupier-Letage, I.: Ocean Mixed Layer responses to intense meteorological events during HyMeX-SOP1 from a high-resolution ocean simulation, Ocean Model., 84, 84-103, https://doi.org/10.1016/j.ocemod.2014.09.009, 2014.

Lellouche, J.-M., Le Galloudec, O., Drévillon, M., Régnier, C., Greiner, E., Garric, G., Ferry, N., Desportes, C., Testut, C.-E., Bricaud, C., Bourdallé-Badie, R., Tranchant, B., Benkiran, M., Drillet, Y., Daudin, A., and De Nicola, C.: Evaluation of global monitoring and forecasting systems at Mercator Océan, Ocean Sci., 9, 57-81, https://doi.org/10.5194/os-9-57-2013, 2013.

Léger, F., Lebeaupin Brossier, C., Giordani, H., Arsouze, T., Beuvier, J., Bouin, M.-N., Bresson, E., Ducrocq, V., Fourrié, N., and Nuret, M.: Dense water formation in the north-western Mediterranean area during HyMeX-SOP2 in $1 / 36^{\circ}$ ocean simulations: Sensitivity to initial conditions, J. Geophys. Res.-Oceans, 121, 5549-5569, https://doi.org/10.1002/2015JC011542, 2016.

Maraldi, C., Chanut, J., Levier, B., Ayoub, N., De Mey, P., Reffray, G., Lyard, F., Cailleau, S., Drévillon, M., Fanjul, E. A., Sotillo, M. G., Marsaleix, P., and the Mercator Research and Development Team: NEMO on the shelf: assessment of the Iberia-Biscay-Ireland configuration, Ocean Sci., 9, 745-771, https://doi.org/10.5194/os-9-745-2013, 2013.

Marsaleix, P., Auclair, F., Floor, J. W., Herrmann, M. J., Estournel, C., Pairaud, I., and Ulses, C.: Energy conservation issues in sigma-coordinate free-surface ocean models, Ocean Model., 20, 61-89, https://doi.org/10.1016/j.ocemod.2007.07.005, 2008.

Marsaleix, P., Auclair, F., and Estournel, C.: Low-order pressure gradient schemes in sigma coordinate models: The seamount test revisited, Ocean Model., 30, 169-177, https://doi.org/10.1016/j.ocemod.2009.06.011, 2009.

Marsaleix, P., Auclair, F., Duhaut, T., Estournel, C., Nguyen, C., and Ulses, C.: Alternatives to the
Robert-Asselin filter, Ocean Model., 41, 53-66, https://doi.org/10.1016/j.ocemod.2011.11.002, 2012.

Marshall, J. and Schott, F.: Open-ocean convection: Observations, theory, and models, Rev. Geophys., 37, 1-64, https://doi.org/10.1029/98RG02739, 1999.

Marsland, S. J., Haak, H., Jungclaus, J. H., Latif, M., and Röske, F.: The Max-Planck-Institute global ocean/sea ice model with orthogonal curvilinear coordinates, Ocean Model., 5, 91-127, 2003.

Masson, V., Le Moigne, P., Martin, E., Faroux, S., Alias, A., Alkama, R., Belamari, S., Barbu, A., Boone, A., Bouyssel, F., Brousseau, P., Brun, E., Calvet, J.-C., Carrer, D., Decharme, B., Delire, C., Donier, S., Essaouini, K., Gibelin, A.-L., Giordani, H., Habets, F., Jidane, M., Kerdraon, G., Kourzeneva, E., Lafaysse, M., Lafont, S., Lebeaupin Brossier, C., Lemonsu, A., Mahfouf, J.-F., Marguinaud, P., Mokhtari, M., Morin, S., Pigeon, G., Salgado, R., Seity, Y., Taillefer, F., Tanguy, G., Tulet, P., Vincendon, B., Vionnet, V., and Voldoire, A.: The SURFEXv7.2 land and ocean surface platform for coupled or offline simulation of earth surface variables and fluxes, Geosci. Model Dev., 6, 929-960, https://doi.org/10.5194/gmd-6-929-2013, 2013.

Michaud, H., Marsaleix, P., Leredde, Y., Estournel, C., Bourrin, F., Lyard, F., Mayet, C., and Ardhuin, F.: Three-dimensional modelling of wave-induced current from the surf zone to the inner shelf, Ocean Sci., 8, 657-681, https://doi.org/10.5194/os-8-6572012, 2012.

Millot, C.: Circulation in the western Mediterranean Sea, J. Marine Syst., 20, 423-442, 1999.

Millot, C. and Taupier-Letage, I.: Circulation in the Mediterranean sea, in: The Mediterranean Sea, Springer, 29-66, https://doi.org/10.1007/b107143, 2005.

Mlawer, E. J., Taubman, S. J., Brown, P. D., Iacono, M. J., and Clough, S. A.: Radiative transfer for inhomogeneous atmospheres: RRTM, a validated correlated-k model for the longwave, J. Geophys. Res.-Atmos., 102, 16663-16682, https://doi.org/10.1029/97JD00237, 1997.

Moon, I.-J., Ginis, I., Hara, T., and Thomas, B.: A PhysicsBased Parameterization of Air-Sea Momentum Flux at High Wind Speeds and Its Impact on Hurricane Intensity Predictions, Mon. Weather Rev., 135, 2869-2878, https://doi.org/10.1175/MWR3432.1, 2007.

Pergaud, J., Masson, V., Malardel, S., and Couvreux, F.: A parameterization of dry thermals and shallow cumuli for mesoscale numerical weather prediction, Bound.-Lay. Meteorol., 132, 83106, 2009.

Pinty, J. and Jabouille, P.: A mixed-phase cloud parameterization for use in mesoscale non-hydrostatic model: simulations of a squall line and of orographic precipitations, Proceedings on conference on Cloud Physics, Am. Meteor. Soc., 217-220, 1998.

Rainaud, R., Brossier, C. L., Ducrocq, V., Giordani, H., Nuret, M., Fourrié, N., Bouin, M.-N., Taupier-Letage, I., and Legain, D.: Characterization of air-sea exchanges over the Western Mediterranean Sea during HyMeX SOP1 using the AROME-WMED model, Q. J. Roy. Meteor. Soc., 142, 173-187, 2016.

Renault, L., Chiggiato, J., Warner, J. C., Gomez, M., Vizoso, G., and Tintoré, J.: Coupled atmosphere-ocean-wave simulations of a storm event over the Gulf of Lion and Balearic Sea, J. Geophys. Res.-Oceans, 117, C09019, https://doi.org/10.1029/2012JC007924, 2012. 
Schott, F. and Leaman, K. D.: Observations with Moored Acoustic Doppler Current Profilers in the Convection Regime in the Golfe du Lion, J. Phys. Oceanogr., 21, 558-574, https://doi.org/10.1175/15200485(1991)021<0558:OWMADC>2.0.CO;2, 1991.

Schott, F., Visbeck, M., Send, U., Fischer, J., Stramma, L., and Desaubies, Y.: Observations of deep convection in the Gulf of Lions, Northern Mediterranean, during the winter of 1991/92, J. Phys. Oceanogr., 26, 505-524, https://doi.org/10.1175/15200485(1996)026<0505:OODCIT>2.0.CO;2, 1996.

Sempéré, R., Madron, X. D. D., and Guieu, C.: The MERMeX Program for the Mediterranean Sea, 389-392, https://doi.org/10.1007/978-90-481-8630-3_70, 2010.

Small, R., de Szoeke, S., Xie, S., O’Neill, L., Seo, H., Song, Q., Cornillon, P., Spall, M., and Minobe, S.: Air-sea interaction over ocean fronts and eddies, Dynam. Atmos. Oceans, 45, 274-319, https://doi.org/10.1016/j.dynatmoce.2008.01.001, 2008.

Small, R. J., Carniel, S., Campbell, T., Teixeira, J., and Allard, R.: The response of the Ligurian and Tyrrhenian Seas to a summer Mistral event: A coupled atmosphere-ocean approach, Ocean Model., 48, 30-44, https://doi.org/10.1016/j.ocemod.2012.02.003, 2012.

Testor, P. and Gascard, J. C.: Post-convection spreading phase in the Northwestern Mediterranean Sea, Deep-Sea Res. Pt. I, 53, 869893, https://doi.org/10.1016/j.dsr.2006.02.004, 2006.

Ulses, C., Estournel, C., Bonnin, J., Durrieu de Madron, X., and Marsaleix, P.: Impact of storms and dense water cascading on shelf-slope exchanges in the Gulf of Lion (NW Mediterranean), J. Geophys. Res.-Oceans, 113, C02010, https://doi.org/10.1029/2006JC003795, 2008.
Voldoire, A., Decharme, B., Pianezze, J., Lebeaupin Brossier, C., Sevault, F., Seyfried, L., Garnier, V., Bielli, S., Valcke, S., Alias, A., Accensi, M., Ardhuin, F., Bouin, M.-N., Ducrocq, V., Faroux, S., Giordani, H., Léger, F., Marsaleix, P., Rainaud, R., Redelsperger, J.-L., Richard, E., and Riette, S.: SURFEX v8.0 interface with OASIS3-MCT to couple atmosphere with hydrology, ocean, waves and sea-ice models, from coastal to global scales, Geosci. Model Dev., 10, 4207-4227, https://doi.org/10.5194/gmd-10-4207-2017, 2017.

Waldman, R., Somot, S., Herrmann, M., Bosse, A., Caniaux, G., Estournel, C., Houpert, L., Prieur, L., Sevault, F., and Testor, P.: Modeling the intense 2012-2013 dense water formation event in the northwestern Mediterranean Sea: Evaluation with an ensemble simulation approach, J. Geophys. Res.-Oceans, 122, 12971324, https://doi.org/10.1002/2016JC012437, 2016a.

Waldman, R., Somot, S., Herrmann, M., Testor, P., Estournel, C., Sevault, F., Prieur, L., Mortier, L., Coppola, L., Taillandier, V., Conan, P., and Dausse, D.: Estimating dense water volume and its evolution for the year 2012-2013 in the Northwestern Mediterranean Sea: An observing system simulation experiment approach, J. Geophys. Res.-Oceans, 121, 6696-6716, https://doi.org/10.1002/2016JC011694, 2016b.

Webster, P. J. and Lukas, R.: TOGA COARE: The coupled oceanatmosphere response experiment, B. Am. Meteorol. Soc., 73, 1377-1416, 1992. 